\title{
THHE PHILLSOPHH OF MUSHC
}

\section{THE ESSENCE}

\section{AND MYSTERY OF MUSIC}

\section{V.M. Rozin}

Annotation. The paper presents a new philosophical concept of music, while the author also draws upon his research experience in the sphere of methodology, culturology and the humanities. It formulates the problems that are to be resolved: to find an explanation for the strong influence of music on a human and different understandings thereof; the irreducibility of music to just technique and sound - making a dilemma: whether music is a language, or a symbolic system. There exists a hypothesis that music, on the one hand, constitutes a life form as a solution of personality problems, and, on the other hand, it represents an artistic reality. Basic characteristics of the artistic reality are discussed: the textual nature, the unity of experiencing and arranging the events thereof, the role of personality. Such notions as "expressive means», «material of art», "artistic form are analyzed, and it is stated that the whole is formed in music by expressive means and the artist's personality. In the last part of the paper, the author substantiates the initial hypothesis about the nature of music, compares music with other temporary art forms, demonstrates that classical music was formed as a life form that allowed a modern-European personality implement the three main aspects of his/her being. A notion of music culture is introduced as another important music characteristic. In the process of the development of the proposed music concept, the author used human cognition methodology, the comparative analysis of different art forms, case analysis, genetic considerations, method of perfect object problematization and structuring. As a result, he has managed to build a new philosophical concept of music, to resolve a series of problems defined in respect of music, and hopes to have partially revealed the mystery of music. An important aspect of such a mystery is that while listening to music a person actualizes his existential problems exactly in the form of musical timing and work involving the reading and artistic comprehension of the musical matter and form.

Keywords: music, event, problem, personality, sound, sound complex, word, life, consciousness, reality.

The point at issue is about philosophical comprehension, which, as you know, can be very different. Here, the author is not only a philosopher, but also has research experience in the sphere of methodology, culturology and the humanities. The practice of thinking in such spheres actually defines the specificity of his approach: I will be interpreting music within the scope of philosophy, drawing on the above three disciplines. According to the methodological practice, it should be started with the definition of problems related to music.

\section{PROBLEMATIZATION}

Though, when speaking of music, the words «wonderful» or «mysterious» are used journalism and popularization field, they are quite justifiable in scientific thinking as well'. The thing is that modern

For instance, Viacheslav Volnov, while trying in an attempt to give a popular version of his understanding of the mystery of the phenomenon of music, gives it the following definition: 'Music is the entirety philosophy and science, including musicology (music theories), while describing separate aspects of music, cannot describe its mystery. By saying «cannot» I do not assert that there are no explanations of the influence of music on a human, of its mystery, - there are quite a lot of them; the point is different: in my opinion, the existing philosophical and scientific understanding of music cannot currently be considered satisfactory ${ }^{2}$. So, what is the author's vision of the mystery of music?

of sounds that evokes the feelings dragging us into listening for the sake of listening alone.' (V. Volnov. Phenomenon of Music) http:// www.v-volnov.narod.ru/SmallWorks/PhenomenonOfMusic.htm).

The reason, why lam uncomfortable with the existing explanations of music and other art forms, I discuss in the works: Rozin V.M. Genesis of European Art (in philosophical and cultural-historical sense). M., 2011; Rozin V.M. The Establishment and Theoretical Reasoning of Classical Music in the Modern-Age Culture // Cultures and Arts. 2013. N 3; Rozin V.M. Speculations of Architecture (a dialogue initiated by Aleksandr Rappaport) // Cultures and Arts. 2013. N 5. 
Primarily, I see it in the strong impact, exerted on us by music, while we hear just mere sounds. It is known that sounds alone do not touch a human, i.e. they trigger our respective signalling and orientation responses: whether sounds are strong or weak, disturbing or neutral, reminding of certain events thunder, a door bell, gunshot, water, etc. However, music, though one can hear only sounds in a certain sequence, can capture a human entirely, while making him experience emotions, which may actually be quite serious. It is also known that until we absorb music, understand it, it evokes no emotions - doesn't touch us - and, on the contrary, even often irritates us'. There is another observation to be pointed out: when we listen to music and try to understand what is going on, sometimes we catch ourselves, on the one hand, "reading» the text of music (we listen to, and distinguish sounds, chords, instruments, transitions from one instrument to another, etc.), and, on the other hand, moving actually within music, going through events already, as if not relying on the text of music. Do we actually get detached from reading the text of music, or is it just an illusion caused by switching our attention to certain, so to say, «non-textual» aspects of music?

There is another moment, which is interesting and unclear to me. And I turn on the music or a pianist strikes the first chord. Though I understand that sounds come from the outside (the feeling is especially clear, when the source of sounds is far away, for instance "a city orchestra plays in a city garden'), I clearly feel that the music actually sounds inside myself - that the source thereof is not outside myself, but it is actually me. But how can it be that way? After all, I don't have a receiver or a pianist sitting inside? They often say that music sounds in our heart (for instance, «Music is the echo of a transcendent harmonious world; it is the sigh of an angel within us.» J.P Richter; "Let music sound in your heart, // While attracting light and warmth. // And let it gather many of your friends, // Who implement together a kind dream», Alla Pevzner). But what is our heart, and how can music sound in it? A man of art needs no

Having served in the army, I, under the impact of my teacher G.P. Shchedrovitsky, started going to a music conservatoire. Back then, Georgiy, together with his friends-seminarians, was very much fond of Prokofiev's and Shostakovich's music; I failed to understand it, but listened for company's sake, and tried to understand. I remember quite well that in the first months I perceived the pieces performed, even by Richter, merely like complex sets of sounds that evoked no feelings in me. At the same time, the music of Mozart and Beethoven had quite a strong impact on me. However, only a year or a yearand-a-half later, my efforts bore fruit: the music of Prokofiev and Shostakovich as it were appeared before me - came alive. Later on, I could understand and feel it more and more clearly. Today I wonder: how couldn't I hear such beautiful music, and performed in such a way. answers to such questions, but it is such questions which arouses the amazement or the speculation of a philosopher or a scientist.

The third issue is purely a professional, or even a semiotic, one. If we speak about understanding music, then music is probably a special artistic language, which a man learns while listening to music. For instance, V. Konen in the book called Theater and Symphony asserts that the meanings of classical music were formed in the modern age for expression in operatic works of fixed images (sorrow, grief, heroism, mental conflict, tender melancholy, pure love, comic actions, etc.) by means of establishing stable meanings of musical expressions (intonation and melodic turns and images) with simultaneous release of such turns and images from poetic (speech) and theatrical support ${ }^{2}$.

However, even earlier, A. Schweitzer demonstrated that drawing on poetic dramaturgy and events (in chants and cantatas) promoted the formation in J.S. Bach's music of steady meanings of musical expressions (expressions of the state of calmness, sorrow, happiness, tiredness, anxiety, the foot of Christ, etc.). Within such an explanation, classical music grows from the system of musical speech expressions, the meaning whereof was formed in music art genres that are closely connected with the word (chants, cantatas, opera), at which point musical meanings developed with the assimilation of poetic textual meanings.

What kind of language can it be - an opponent may object - when no exact meanings can be established? It is known that everybody hears and understands music in his own way. Therefore, a series of researchers flatly reject the language-based interpretation of music; the most well-known names among them are: E. Hanslick, E. Kurth, S. Langer. For instance, the latter sees music not as a language, but as a symbolic system. According to V. Shestakov, Susanne Langer "finds rational meaning in those music theories, which view the symbolic meaning therein as an expression of something impersonal life instinct, will. It is a comprehensive symbol of vital processes, both intellectual and physical ones. Music is a presentational symbol of physical processes, such as growth and development, ups and downs, tension and release, excitement and dreams. Music is no imitation of the sounds of nature - songs of birds, patter of rain, etc. Music is expressive. It constitutes the expression of human feelings, however not in the sense of conferring someone's feelings (those of composer or performer), but only in the sense of isomorphism, the unity of structure of the subsequent development

Konen V. Theater and Symphony. M., 1968. 
of human feelings and the development of tones in a piece of music. In other words, music is a tonal analogy of emotional human life.»1

It would also be a good thing if we could comprehend such a phenomenon as the higher, ecstatic forms of feeling music, when it takes us to some other spheres and worlds, makes us forget ourselves and experience condition, which are very difficult to put in words. For instance, here is a recollection of Sviatoslav Richter about Prokofiev's music: «I had one of the strongest impressions from the performance of his Symphony No. 3 in 1939. It was conducted by the composer. I have never heard anything similar before when listening to music. It had effect on me like doomsday. Prokofiev uses super- intense expressive means in his symphony. In the third part - the Scherzo - the strings play such a brisk figure, in the same way that wisps of smoke fly when something burns in the air. The last part starts in the mood of a sombre march - grand masses yawn and overturn - «the end of the universe», and then after a little quiet interval everything starts over with the double strength accompanied by knell. I was sitting there and didn't know what would happen to me next. I wanted to hide. I looked at my neighbour - he was all wet and red... In the entr'acte, it was still giving me the creeps ${ }^{2}$.»

Something to add here. "My father admitted the value of Prokofiev's music, but it was too extravagant for him. «lt is awful - he used to say - as if you get constantly slapped in your face! And then you go again ccrrash! And again... ready: ppakh!» ${ }^{3} . »$

It is quite odd: something that forms the highest levels for one listener is only «Ccrrash! Ppow!» for another.

\section{INITIAL BASIC ASSUMPTIONS 4}

Now we need to give answers to the above-defined problems. Here, I will not compare philosophical and scientific discourses, I will refer to the essence of music (which is a purely philosophical aspect). However,

Shestakov V. Aesthetic Philosophy of Susanne Langer. http://philosophy.ru/library/langer/pril.html

Cited by: S.S. Prokofiev. Materials. Documents. Memories. M., 1961 P. 459. And when Gould was listening to Schubert performed by Richter, he was in a state, as he put it, close to that of a hypnotic trance (Tina Gai The Doubles: Richter - Gould http://sotvori-sebiasam.ru/svyatoslav-rixter/).

S.S. Prokofiev. Materials. Documents. Memories. P. 461.

Compare. 'Any essential thinking,' writes M. Heidegger, 'requires the thought and states to be every time just like metal melted anew out of the underlying spirit. If the underlying spirit is absent, all the rest is just the forced ringing of notions and verbal shells... Thinking of the being, as an event, is the initial thinking that like dissociation with the first beginning prepares another one. The event is a secure light of fulfilment of the being in the very extreme horizon of the inner need of a traditional human.' (Heidegger M. Contributions to Philosophy. (Of the Event) "Epunveía N 1 (1) 2009. P. 60-70.). at the same time, I will draw on the methodology of human cognition (which already relates to the competence of science). Within the human cognition, (and I demonstrate it in my work Features of discourse and examples of research in humanity) a researcher creates «perfect objects» representing a phenomenon being studied (which is music in this case). At the same time, he parallels the principles of human approach: «resolves his existential situation, actualizes his own values and vision, analyzes the text and personality behind it, «makes a studied phenomenon speak»,» (M. Bakhtin), which can be regarded as the recognition of the integrity and activity of the phenomenon under consideration ${ }^{5}$. A researcher ascribes such characteristics to perfect objects, which allow viewing the objects as a description of a phenomenon being studied, imagining such phenomenon in a non-contradictory manner, and developing a scientific (which in this case is philosophical and human) explanation. This work represents a philosophical development (apprehension) only when perfect objects are formed, not just for the purpose of understanding and implementing human principles, but also for establishing a new reality - a new understanding and vision of music — and means for its cognition. In other words, I will characterize music by expanding on both discourses the philosophical and the scientific (human) one, while subordinating the second to the first.

In order to start, I would like to draw your attention to the contraposition of music and musical technique (art) that is constantly highlighted by many critics, musicologists and artists (composers and performers). Though, as they say, no music exists without correct and sophisticated performance techniques, music cannot be reduced to technique alone. As Yelena Obraztsova recently said in a series of TV shows: «I don't sing notes, I sing music. ${ }^{6}$ So, what is music, which is not reduced to the technique of its performance?

Well, one should still agree with the viewpoint that no music exists without sophisticated performance technique, and without musical instruments. (By the way, the voice is also a delicate musical instrument, and a dancer generally has a complicated technique). The first drums and ancient pipes demonstrate that already.

Another consideration, which is of equal importance, is as follows: the true, serious music makes us feel not only the personality of the composer and performer, but even the epoch and its challenges. Let's take, for instance, the memoires of A. Schnittke about Prokofiev. «Meanwhile,» he writes, »the beginning of

Rozin V.M. Features of Discourse and Examples of Research in Humanity. M. 2008. P. 127-135.

Compare: 'Sviatoslav Sulima, the younger son of the composer, recalls an episode, when Stravinsky reproached the performers of his Concerto for Two Pianos that they 'played only notes, and had no idea what to do with them.' http://lib.rus.ec/b/354987/read 
the XXth century promised mankind the long-awaited safety of the historic route. Wars, well, in any case the great ones, seemed to be impossible already. Faith was forced out by science. Any unmastered obstacles had to fall soon. Thence - the cold, sportsmanlike approach to life had its focus on the most useful and the most spiritualized things in the destinies of young people, including Prokofiev. That was the natural optimism - not an ideologically inspired one, but of the most authentic character. It was the multifaceted self-identification with the epoch and its attributes - express trains, automobiles, airplanes, telegraph, radio and so on, - that gave the sobering rhapsodic, achieved once and forever, most precise time organization, which found its reflection in Prokofiev's everyday habits as well... Apparently, each man remains what he was from the very beginning on all turns of his path, and time can do nothing about it. It should only be mentioned here that the cheerless roots of the being were not strange to Prokofiev either. Suffice it to recall the auto-da-fé scene in The Fiery Angel or the scene of Prince Andrei's death in War and Peace, just like numerous tragic and dramatic turns in the form of, for instance, Symphony No. 6 or Piano Sonata No. 8 or Violin Sonata No. 1. The same is in the String Quartet No. 2 and in the Five Poems of Anna Akhmatova. And what about the brilliant double-murder scene in Romeo and Juliet? For too long, this most serious music was judged only by its daring cover, paying no attention to the deeply felt essence. Everyone saw the carnival glitter of the outer world, while disregarding the seriousness strict seriousness that was keeping the suffering from pouring out and flooding everything around. And the seriousness was actually present in Prokofiev from the very beginning! Just think of the Piano Concerto No. 2, of that still controversial sound-world resonating with severity and cruelty; of the Scythian Suite, Ala i Lolli, a very peculiar «shadow version» of The Rite of Spring; of Piano Sonatas No. 2 and No. 3, and of many other things. This man certainly knew the ugly truth about his epoch. He just never allowed it to depress him. His thinking remained within the classical frames, and that made the tragic power of expression in all his gavottes and minuets, waltzes and marches, even greater.»'

Music doesn't exist without its comprehension, without musical knowledge and theories, and without musical thinking either. According to the paradoxical saying of A. Skriabin: «Music stays alive by thought.» Pythagoras has already proposed measuring the scale for the intervals between sounds, and Aristotle writes his Poetics, where he discusses the essence of art, including music, and formulates the rules one should follow to create good pieces of art. A good musician cannot imagine music without musical grammars and

Schnittke A.G. The Song of Prokofiev // Conversations with Alfred Schnittke. M., 1994. P. 210. theories, and a listener - without interpretations and understanding of pieces of music.

Thus, music is not just notes, and it is not a performance technique. Here is a counter thesis: music is a complex technique - musical instruments and the art of making a performance. Music somehow immerses us in an epoch (past or modern one), introduces us to the artist's personality, and makes us see and feel the invisible. While it's only a stream of sounds. Music is musical knowledge (musical thinking), though many musicians deny this fact ${ }^{2}$. One may ask, how all of that should be understood, and whether such characteristics of music are consistent.

Before answering the questions, I'll first quote one youthful recollection of a well-known psychologist, Carl Jung. The content of the experience is as follows. Once, on a fine summer day of 1887, Jung, delighted by the universe, thought: «The world is beautiful, and the church is beautiful, and God made all this and sits above it far away in the blue sky on a golden throne and ... Here came a great hole in my thoughts, and a choking sensation. I felt numbed, and knew only: "Don't go thinking now! Something terrible is coming.»

(After three tough days filled with internal struggle and rueful feelings and sleepless nights, Jung still allowed himself to complete the thought that he had started that seemed innocent enough.)

I gathered all my courage, as though I were about to leap forthwith into hell-fire, and let the thought come. I saw before me the cathedral, the blue sky. God sits on His golden throne, high above the world — and from under the throne an enormous piece of shite falls upon the sparkling new roof, shatters it, and breaks the walls of the cathedral asunder.

So that was it! I felt an enormous, an indescribable relief. Instead of the expected damnation, grace had come upon me and with it an unutterable bliss, which I had never known... A great many things I had not previously understood became clear to me. That was what my father had not understood - the will of God. Father had taken the Bible's commandments as his guide; he believed in God as the Bible prescribed, and as his forefathers had taught him. But he did not know the immediate living God who stands, omnipotent and free, above His Bible and His Church, who calls upon man to partake of His freedom. God can force him to renounce his own views and convictions in order to fulfil without reserve the command of God. In His trial of human courage God refuses to abide by traditions, no matter how

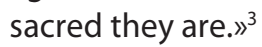

\footnotetext{
'Music,'writes S. Richter,'created for playing and listening, needs no words - any speculations thereon are absolutely needless - besides I never had the gift of the gab.'(Tina Gai The Doubles: Richter - Gould http://sotvori-sebia-sam.ru/svyatoslav-rixter/).

Jung C. Memories, dreams, reflections. Kiev, 1994. P. 46, 50.
} 
We are facing a complex scheme and a new vision of reality, which took Jung three days to achieve. It prescribes not only a new understanding of God, but also a focus on practical action - a break with the Creator. Let's discuss it in more detail: the first question that arises here is why such an interpretation of thoughts should be considered as fulfilling the command of God and not, vice versa, as heresy and a denial of God? After all, Jung came to the point, when God made him deny the Church, and the sacred religious traditions as well. The second question, which can be even more important, is why Jung actually admits such an interpretation of his thoughts? The material of his recollections is quite sufficient to answer both questions.

At that time, young Jung was concerned about two existential problems. The first one was his relations with his father, a hereditary minister of church. In Jung's opinion, his father was dogmatic about executing his duty: while having religious doubts, he wasn't trying to resolve them and wasn't free of Christianity and God at all. The second problem was in building his own relations with God, and the clarification of his attitude to the Church. Some time after the period under discussion, those problems were dramatically solved by Jung: he broke, in spiritual terms, both with his father, and with the Church. After the first sacrament, Jung arrived at a decision, which he perceived as follows:

«l found the absence of God in this religion. I knew that I would never again be able to take part in this ceremony. The Church is a place I should not go to. It is not life which is there, but death. I was seized with the most vehement pity for my father. All at once I understood the tragedy of his profession and his life. He was struggling with a death whose existence he could not admit. An abyss had opened between him and me, and I saw no possibility of ever bridging it, for it was infinite in extent..»

This is the direction in which Jung's thinking evolved. On this road, he needed support, both rational and personal. But who could support Jung, when he was breaking with both his father and the Church? The only support for Jung was his own self, or how he later used to say, «his demon». And still Jung understood the process in a different way: as a clarification of the true wish and command of God. It is such inadequate comprehension of what was happening that determined the peculiarities of understanding and interpretation by Jung of his thoughts. Jung, while independently making another step in his spiritual development, perceived it as an order from without, from God (further - from the unconscious, from archetypes), though, in fact, he only tried to justify and explain his step. The correctness of such understanding was also

Ibidem. Page 64 demonstrated by Jung's interpretation of God. God for Jung was his own freedom and later, according to his favourite ontology (theory) - the unconscious. Therefore, Jung happily fulfilled the demands of God, who commanded him to be free, to follow his demon, to resign himself to the unconscious.

Thus, we have to admit that Jung ascribed to God what he actually needed himself. How did he do that? He created a scheme, in which God looked like a true revolutionary. However, the precondition for such creation was the work of his mind, which tried to solve the existential problems Jung was facing; as a result, his mentality produced a God-struggling fantasy to Jung. However, without the subsequent three days of reasoning that allowed the invention of the scheme of God the revolutionary, the new reality would never have appeared. In other words, Jung's existential problems, his fantasy, his understanding thereof and invention of the scheme, were the aspects of the whole that can be called «the establishment of a new reality». It should be noted here, that all those processes were accompanied by strong desires, feelings and emotions. That is, probably, another step or side of the establishment of the new reality.

But how is that, one may ask, related to music? I think, directly, while helping to express a hypothesis or, rather a basic assumption, about the essence of the latter. Jung was led by an existential problem (he was going toward the break with his father and the church), but when we listen to music, don't existential problems drive us as well? Aren't we worried (and "worry» according to Heidegger is something that conditions the transitory nature of our being) so much so that we are able to solve our problems in music? Jung's initial material was spontaneous fantasy, but the understanding and the ordering of that leads to a new reality (God as a revolutionary). Can we then draw the following analogy? The initial material of music is represented by a sounding flow, but the music itself is, on the one hand, an organized sound complex (organization of sounds by pitch, rhythm, harmony, etc.) and, on the other hand, - a unique reality (artistic, musical)? The necessary condition for understanding the whole situation by Jung was his creative ability and feelings: he had to understand and reimagine the fantasy, create a new image of God, find a place for Him in existing ideas. Don't creation, performance and listening to music imply similar processes: the understating, reimagining and feeling of something that sounds; the creation of a new image (form), finding a place for it in consciousness? Having transformed the questions into formulation of a basic assumption, we get the following: Music constitutes a reality that is revealed and created by $a$ human, who settles/implements his problems/desires by means of such art. The aspects of such reality as a whole are: the very such problems, and reading the text of music, and going through musical events, and understanding 
music- the knowledge of it. But certainly it is necessary to reveal the peculiarities of man's life and activity in art, and in the very artistic reality, which is formed by man and in which he simultaneously lives and acts.

\section{GENERAL CHARACTERISTICS OF ARTISTIC LIFE AND ACTIVITY, AND REALITY}

M. Bakhtin, when discussing the specificity of the human approach, noted that humanity deals with «texts», or «expressions», behind which a personality stands. Speaking about the whole, let us spotlight two of its aspects: the life and activity of a personality, and the artistic reality presented in the text. Let us first consider general characteristics of reality set out in the composer's thought about «psychic realities». «A writer,» M. Ya. Poliakov writes, «in a particular social and literary situation, performs certain social functions while making a transition from social reality to the artistic one, and forming a certain conception of values or, rather, conception of life, in a «system», or «ensemble» of images» ${ }^{1}$. At the same time, according to Ts. Todorov, a reader "proceeding from a literary text, performs a certain work, as a result whereof his consciousness forms a world inhabited by characters similar to people we meet «in life» (it should be mentioned that everything mentioned here also relates to music, V.R.).

Meanwhile, as a rule, many art theorists, while taking a cue from Aristotle, explain that artistic reality is mere «mimesis, a reflection of real world, a quasilife. I have a different opinion: a work of art has to be defined exactly as the world, in which a human lives a full life ${ }^{3}$. We have to remove the mode of imitation,

\footnotetext{
Poliakov M.Y. Issues of Poetics and Artistic Semantics. M., 1978. P. 18. Todorov Ts. Poetics // Structuralism'for'and'against'. M., 1975. P. 63. While comprehending Aristotle's understanding of art, $M$. Heidegger writes that'a work of art reveals, by its means, the being of things in existence. Creation fulfils such revelation-discovery, i.e. the truth of things in existence.'(Heidegger M. Works and Reflections of Different Years. M., 1993. P. 72). Mirab Mamardashvili writes about the same thing, but in a slightly different manner, saying that a work of art gives birth to both, an artist and a spectator. 'In the XXth century, I clearly understood the old truth that a novel is something that for the first time also gives birth to the author of such a text as a personality and a living human, who does not take precedence over his message as a'wicked' or 'kind'man. It is in this sense that it turned out that literature, in general, is not the external 'attachment' to life (an entertaining or an educative one) and that before the text there exists no message the author could have addressed a reader with. And something that he wrote constitutes the womb, in which he for the first time became his actual individual self, having at the same time broken free of something, and having gone through certain things by means of the text. My evidence was unknown to me as well - before the book.' (Mamardashvili M. Literary Critics as a Deed of Reading // The Way I Understand Philosophy. M. 1990. P. 158). In other words, art is no mimesis, but a form of full life.
}

quasi illusion and assert that the portrayal of reality in a work of art, notwithstanding the predetermination, deliberateness and artificiality, fully constitutes a creation of an independent reality, in which an artistic world is formed and expanded fully and adequately for human perception, consciousness and feelings.

A characteristic feature of artistic reality is the textual conditionality of its world; it meets not only the logic of subject relations (the logic of event formation), but also the logic of the formation of the «text» of the work of art. The world of artistic reality is organized and structured, and expands under the laws of genre and similar conditions, and, at the same time, such a world is full of objects, events, and it ranges within the ordinary world. "The task is,» M. Bakhtin wrote, «to make the object-based environment, which mechanically influences a personality, speak, i.e. reveal a potential word and tone in it, transform it into a meaningful context of a thinking, speaking and acting (as well as creating) personality. In fact, every serious and deep confession, autobiography, lyrical poem, does that... An object, while remaining an object, can impact only similar objects; and in order to influence personalities, it has to reveal its semantic potential, to became the word $^{4}$ (consequently, «to become music» $-V$.R.).

Thus, though events in each reality are perceived as natural, taking place of their own accord, beyond human will and desire, most of them are created by a human. Reality is not just a special world, the being, but also a structure (semantic, sign, textual) created by human activity. Such a feature of every reality the simultaneity of constructing and being, engineering and suffering - is quite unique. Consciousness usually notices only the natural part of any reality: certain events, objects, their change and substitution, relations between them, etc. Speaking of the artificial part, even in such realities as art, cognition and playing, it is admitted only by experts, and still not always (for instance, only art experts distinguish for investigation the fact that the world of events described in pieces of poetic art is rhythmically organized, thematized, tonally and syntactically structured, unfolds by the laws of composition, etc.).

It may seem that I am referring only to the perception of works of art. No, the specified peculiarity is also characteristic of other symbolic realities. The worlds given to a human within ordinary perception or, on the contrary, in dreams, not just merely exist, prevail in consciousness, while demonstrating the natural flow of events, but they simultaneously get created and generated by the work of a human. A human does not just see or hears, or just thinks, but constantly marks and structures the objects given to him, fills them with a cer-

Bakhtin M.M. To the Methodology of Literary Studies // Context. 1974. M., 1975. P. 208. 
tain order, logic, relations, and maintains the expanding world, keeping it from destruction and alien impacts, and plans and expects further evolution of events. And all that in the situation, when he himself is actually present in the very reality, when he perceives and experiences events, which naturally take place during them. Thus, we can conclude that natural events of reality constitute the result of life and activity, i.e. of artificial structuring.

However, there is another idea, which can be traced in Bakhtin's sayings: life in art is no imitation or expression of the other, real life, but the authentic, true life, but only flowing in the form of a work of art (word, melody, rhythm, etc.). In order to explain it to you, I'll give one example. A teacher plays a simple major melody to my three-year-old daughter and says: "Look, Vera, how cheerfully a little goat is hopping.» But I can see that my daughter cannot understand it: she does not see a little goat in the room and does not connect the played melody with what the teacher says. I start thinking: indeed, she saw a goat in the country and she is being deceived now, when playing the piano. But the teacher seems not to notice the child's bewilderment, and keeps on insisting that a little goat is cheerfully hopping on grass. To my amazement, a couple of weeks later I notice that Vera, while listening to the melody played by the teacher, can already see the cheerfully hopping goat and understands that the melody is a cheerful, major melody. By the way, I remember me several days ago in the country showing her a little goat hopping on grass and saying: «Look, Vera, how cheerfully is that little goat hopping little goat, - and couldn't help but beat - tam-tam-tam.» I can also recall my research of visual perception, when I asserted that a human can make the experience actual of having perceived a certain object not only on the material of such an object, but also on semiotic material (of a drawing or melody), as well as in a night dream already without any visual material. ${ }^{1}$ Then it is clear what actually happened. Vera knows that whenever father and teacher, when hitting the keys, say «Look, a little goat is hopping cheerfully,» it means that there has to be both «a goat» and "cheerful hopping». It is quite a strong child's desire to coincide with an adult sooner or later which causes the actualization of the experience of the perception of the goat and feeling based on the material of the melody of the music. At that moment Vera starts seeing and hearing a cheerfully hopping goat in the melody, though, certainly, not quite an ordinary one, but, so to speak, a «musical» goat. However, it doesn't make the goat unreal - it's just that there exists a regular goat in the country, and a musical goat in the melody. At this point, the musical goat constitutes no sign or scheme of a regular goat

Rozin V.M. Visual Culture and Perception. The Way a Human Sees and Understands the World. Ed. 5. M., 2012. (it is something like a goat of a different breed), though for solution of certain tasks, for instance, let's imagine that a teacher asks a student to describe a country goat in musical terms, and a musical goat can be presented in the image of a regular goat.

Let us try to develop further the understanding of what is going on here, i.e. the establishment of musical reality. The teacher and I helped Vera correlate the sounding melody and a goat's movements. Vera started not only perceiving the hops of the latter, but, in fact, organized them in accordance with the pitch of sounds, their rhythm and time. There already appeared the contours of the musical goat, as hops of a regular one were not usually prompted by music. The result was different. Behind the sounds, Vera started seeing or, rather, hearing, the goat's movements and then other realias: fall of rain drops, clapping hands in a game and other associations prompted by adults or discovered on her own. What is important here is that they were different, which made her understand that music was not just separate object-based associations, but something different, independent. Our assistance was not limited to something we said: we helped Vera, when listening to one melody, to set herself up for a certain mood (cheerful) and compare it with a different (sad) mood whenever a different melody sounded. Thus, Vera started catching her moods: whenever music sounded, it could be interesting, pleasant, cheerful or sad, or scary. The practice of listening carefully to music, work with a teacher (including solfeggio) sooner or later helped Vera clarify, discover what music was, clarify the fact that it was performed, composed, different from non-music, that it could be felt, that it had appeal (beautiful, interesting). That is, music was already perceived as a reality different from other realities.

It will be no exaggeration to say that in the course of music education Vera developed new ear for music (a new organ of hearing) that allowed her read the text of music, actualize and experience separate musical events (implying particular associations, but not reduced thereto), and, on the whole, live, be within music, while it sounds, and actively listen to it. A new ear for music is similar to the ability to enter the world of music and enjoy it, or use music for different purposes (as a condition of communication, fulfilment of personality, etc.). I suppose, other children pass similar stages, though, of course, a lot depends on the background and art education.

Observations demonstrate that very small children have no clear differentiation of conscience and activity into separate realities, they have, so to say, only one prereality, where the facts of practical life, games, dreams, fantasies, adults' stories, pictures, etc. interweave and fail differ in value terms. In early childhood, sounds, colours, motor and plastic movements, drawings, any art material, are perceived exactly like people, animals, 
objects. The situation changes radically further, when in the process of bringing up and education an adult demonstrates to a child the correlations and connections of semiotic art materials (words, sounds, colours, movements) with certain objects and interior life conditions inherent therein (images, feelings, emotions, that are directed at such objects, caused thereby). A child obtains a strong desire to understand an adult, be in line with him in respect of what the latter hears and sees. As a result, from a certain point a child starts seeing (hearing) such objects in the material of art pieces, and soon makes sure that they slightly differ from the regular ones. Meanwhile, its conscience develops an art-specific dual attitude (though sound is just sound, it may evoke sadness or happiness; though a drawing is just a trace of slate pencil, words are just sounds, they may also be a human, an animal, the sky and the sun). In fact, such attitude is aesthetic in the broad sense. For instance, the world and events in music are independent, real-life, thought they are manmade and also remind of the usual world beyond music.

An important part in the establishment of the reality of art is played by figures. They allow not only the solving of problems, a child's faces, (to understand an adult, to see and to hear the same things he does), but also defining a new reality (a musical goat, a cheerful melody), which also constitutes a condition for new behaviour. (From that moment on, a child can live in art events and later - create works of art himself)'.

When getting acquainted with a musical work, a «reader», or appreciator, not only learns and understands the text of such a work, going into its intonation and phonetical connections, its rhythm, time, syntax, meanings, topics, drama, but he recreates or creates a full world (of objects, and events). The aesthetic attitude allows entering into such a world, feeling its reality, living a full life in it, ${ }^{2}$ and at the same time understanding its conventionality, artificiality, its manmade nature, where such an understanding not only keeps artistic reality undestroyed, but, on the contrary, it strengthens it, while turning the conventionality of artistic means and language into a pattern and course of things and relations of the artistic world.

About schemes, see Rozin V.M. Introduction into Schemology. Schemes in Philosophy, Culture, Science, Designing. M., 2011.

Compare. One should, according to Bakhtin, 'as a creator enter something he sees, hears, utters and, thereby overcome the material non-creative, defined character of the form... when reading and listening to a piece of poetry, I do not leave it outside myself as an utterance of someone else... but l, to a certain degree, make it my own utterance about someone else; I adjust to myself its rhythm, intonation, articulatory strain, internal gestures... as an adequate expression of my own value-based attitude to the content... I become active in the form, and by the form I take a value-based position beyond the content - like cognitive-poetic orientations.' (Bakhtin M. Issues of Literature and Aesthetics. M., 1975. P. 58-59).
Within the act of verbal expression and communication, the world of artistic reality is actually constituted in language and through language, according to R. Yakobson and his followers, but in the acts of feeling and experiencing events the linguistic reality turns out to be just an element of the artistic reality. The artistic reality is formed not only with the help of artistic language, though it is the latter that takes a spectator (reader) into the world of the artistic reality, but also on the basis of the realization and creation of the world itself (its objects, events, situations). Language helps penetrate such a world, defines its segmentations and connections, but stops at the boundary of the very objectivism generated in other processes - the objectification, the discovery of events, understanding and going through them.

Let's have a look at the quatrain of Marina Tsvetayeva, as an example:

\section{"Just like a warm tear - \\ A drop falls in my eyes. \\ There, up in the sky, \\ Someone is crying for me.»}

It is clear that language takes us to the artistic reality defined by the quatrain. However, the very events of such reality - an image of a guardian angel, the Mother of God, or Christ, who suffers for us - are created not with the language, but with the help of expressive means and our imagination.

Thus, an artist creates his work as a world of events that a spectator goes through. Meanwhile, he has to invent such an artistic form, interconnect his expressive means in such a way, so that the world can be perceived by a spectator as absolutely natural and seamless. One of the approaches lies in the confirmation of artisticreality events. The necessary condition of experiencing and the confirmation of such events is actually formed by an understanding of the conventionality of the artistic-reality world (though, as Leonardo da Vinci used to say, we have paints and the plane, we see retreating fields and meadows), by the ability to define the genre of the work, read its text, feel and so on. One reality is, as a rule, contraposed to others; thus, the artistic reality is compared to the scientific one, with reality of night dreams, with everyday life. In order to plunge into the world of artistic reality and go through its events, one needs a special attitude, but in order to exit a reality and switch to a different one, an act of switching is also required ${ }^{3}$.

\footnotetext{
For more details on the reality and artistic reality, see the author's works. Rozin V.M. Visual Culture and Perception. The Way a Human Sees and Understands the World. Ed. Second. URSS. M. 2004; Psychology: Science and Practice. Study Guide. OMEGA-L. M., 2005; Mental Reality, Abilities and Health of a Human. M., 2000; Semiotic Studies. M., 2001;
} 
A human gets into the world of artistic reality from the regular world, so he lives through the events of artistic reality also as a person, who was motivated and established in other realities (in everyday life, regular life practice, in science, etc., - everybody has his own trail of the past and the present). Therefore, regardless of special attitudes (for instance, aesthetic ones) and the availability of artistic consciousness, a mandatory condition for existence of art lies in setting the relations between art and other realities. Already in the Poetics, Aristotle gives characteristics to such relations, but in a different way: as imitation, as a requirement of wholeness (scope, involuntariness, believability, etc.). Similarly, Alberti, but already at a new level and for his art practice, sets such relations, speaking of beauty, "history», wholeness, etc.

Let us draw some conclusions. Art is a fullyfledged reality, a true life. Necessary preconditions for the establishment of such reality are represented, firstly, by strong desires of an individual formed by an intersubjective situation, secondly, by the processes of denotation and pattering, and, thirdly, by the formation of an aesthetic attitude. But those are only the first steps: laterr, personality and artistic culture get into the game. And still, are realities connected with personality? Certainly they are, and here is in what respect they are connected

As it was mentioned above, a very small child is practically unable to differentiate realities: he has one "prereality». A child mixes up reality and dream (night dream), reaches to take a painted apple. Different realities don't appear in a preschool child either, though it already clearly distinguishes his parents and himself, night dreams and visual impressions of the life awake, regular activity and games, etc. A preschool child can say a lot about himself and even to a certain extent realize and assess his wishes and abilities.

Different realities start forming only together with the acceptance by a primary-school child of requirements to the independent behaviour and actual need in such behaviour in school and in out-of-school life. In its turn, a switch to independent behaviour entails an important anthropologic metamorphosis: a personality starts to develop, i.e. there develops an individual, who independently organizes the exterior world and himself as a unique world.

At an earlier stage, it was parents and adults, who prompted a child what to do in a new way for the child, or in an unusual situation - how to behave, what can be wished and what cannot, supporting the child in difficult moments of his life, controlling it, etc; then, later, with the appearance of demands to show independence a teenager has to do the prompting himself - permitting or forbidding, supporting himself, guiding himself, etc.
The necessary condition for the development of independent behaviour lies in the detection and discovery by a teenager of his individual self, in ascribing certain qualities to himself: I am such and such, I lived, I will live, I saw myself in a dream, etc. ' The individual self of a human is paradoxical: this is someone, who gives advice, guides, controls, supports, and is also the one to whom such advice, guiding and support are addressed. Though the content of the «image of oneself", of the individual self is, as a rule, taken from the outside together with borrowing of external images, it is viewed by a teenager as something inherent in him, as his abilities, character, desires. A teenager usually fails to realize the artificially-semiotic plan of his behaviour; he experiences all those actions regarding the «image of himself» as natural, genuine conditions, as events he actually goes through.

Another necessary condition for independent behaviour is, in fact, the formation of different realities. Indeed, the development of independent behaviour involves planning and the anticipation of future actions and feelings, the change of one means of actions and forms of behaviour to another, where a teenager has to do all that himself. Similar plans and anticipations, changes and refocusing of consciousness and behaviour, are initially prompted and come from the outside, from an adult (so it is no independent behaviour yet). In theoretical terms, they can be interpreted as "guiding schemes»" But gradually a teenager himself learns to build the schemes defining the reality (I call them «private schemes») that provide for independent behaviour. It is from the point, when the set-by-private-schemes plans, anticipations and refocusing become the necessary conditions for independent behaviour, when they are viewed and realized by a human as different conditions under which he acts, a teenager opens different realities for himself.

Thus, realities of a personality are not just a chain of events that define the activity of an individual and his logic, but also external and internal conditions for independent behaviour. It should be underlined that the discovery and formation of the individual self of a human and formation of different realities are two sides of the same coin. As the differentiation of a human's realities becomes more complex, his individual self becomes more rich and differentiated, and vice versa. However, their functions are diverse: realities characterize the behaviour-adjusted world, where a

Certainly, a child used to say 'I' before, but that his 'I' had an absolutely different content: it is me, and not someone else: I am Peter, I am the one who wants, has something, sleeps, eats, etc.

Rozin V.M. Semiotic Studies. M., 2001; Rozin V.M. Introduction into Schemology. Schemes in Philosophy, Culture, Science, Designing. P. 133-141. 
human builds his independent behaviour, and where his individual self sets the main milestones and lines for the unfolding of such behaviour. In simpler terms, we can say that reality constitutes projections of independent behaviour on the outer and inner world, and the individual self constitutes an understanding of independent behaviour as a subject.

The above-described way of the formation of realities and their peculiarities can be used to describe how a single child's prereality gradually develops into differentiated spheres of night dreams, game, communication, reasoning and speculation, the sphere of art and a series of other spheres, each of which forms independent realities. The formation of each such sphere and its realities involves not only the distinction of life events and phenomena, different attitudes to them and the evaluation of them (in a game they are of some kind, in work activity of another, in communication of still another, etc.), but also the acquisition of the specifics for the «semiotics» of each sphere (the heart of which is formed by private schemes) and the «logic of life» (something, which is admissible in one reality, is often forbidden in others, events within each reality have their conditionality).

\section{EXPRESSIVE MEANS, "THE MATTER OF ART" AND ARTISTIC FORM}

As was already mentioned, artistic reality gets created, and is not just lived through and perceived as the naturally existing artistic world and events. It is created on the basis of a specific semiotic matter (sounds, words, colours, etc.), expressive means (vision of a melody, harmony, rhythm, topics, drama, formcomposition, etc.; such means are different for different art forms) and artistic form. At first sight it may seem that the most important thing here is the matter of art. For instance, in music, it is pitch sequence (timing) and organization; hence, we have an argument that music is "temporary» art (which is understood absolutely differently from what Heidegger meant). «Extensive argumentation of such opinion,» writes I. Malyshev, «is given in the recently published book of M.S. Kagan Music in the World of the Arts. According to the author, music positively constitutes the temporal art; it is "as though time itself materialized in sound structures». Its pieces really exist «as the unfoldingin-time sonorant processes, in which its spiritual content also moves. A music piece lives in time - it comes into being, flows and disappears together with the end of its performance.» This is what makes music different from other — spatial — art forms, and from the current reality. Reality exists in both space and time. However, «one of the most essential features of art is its ability to separate space from time.» What is actually peculiar about music is that it separates «chronos (Greek -time) from topos», while using the «dynamic structures set free from spatial characteristics, »- M.S. Kagan thinks.'

Well, let's think what the perception of a musical sound is. After all, we hear not the stimulation of an auditory nerve, but a musical tone, theme, melody. An auditory image, as the whole, appears when sonorant information meets the actualization of our «hearing experience» (Helmholtz). In their turn, they are formed on the basis of many components: the actual active listening to music, and the implementation of knowledge and understanding.

Malyshev argues against M. Kagan's position, while demonstrating that the whole is formed not by the musical matter, but, rather, by expressive means, within the scope of which the matter exists. Here is his speculation: «Doubts are generated,» he writes, «primarily by the two interrelated provisions: first of all, by the fact that the subject of ontological analysis is represented by the material being of a piece of music and, secondly, that the material sound form of a piece acts as such in music. The thing is that sound is immaterial. Sound is the subjective feeling of acoustic vibrations in the medium of air. It is those vibrations that actually constitute the objective reality, i.e. "the matter». However, the form of a piece of music is actually acoustic. Both the aesthetic impact on a listener and its communicative function - the transfer of its spiritual content - are executed not by the airmedium vibrations alone, but by their auditory image in the listener's consciousness. Therefore, the subject of ontological analysis must include the subjective (immaterial) reality of the existence of a piece of music's sound form... Indeed, sound sensations appear and disappear; sound impressions follow each other, while embodying thereby the «pure procedure», spaceless temporality.

However, a musical theme constitutes no sequence of sounds, but a system of intonations. Even if a theme were a mere sum of sound sensations, it would still differ from their temporal sequence, as it would involve the saving of what had sounded. But as a systemic integrity, the theme does not equal the sum of the intonations it is composed of - this is on the one hand. On the other hand, even a separate intonation acquires its final meaning only in the context of the whole, i.e. of a theme. Therefore a theme, as a whole, exists timelessly. Its elements - intonations coexist, but do not appear and disappear in time. The same thing, and even to a greater extent, is true of the form of a piece of music, on the whole. Moreover, it is true not only of the form, but also of the content, i.e. of a piece of music in its entirety. What is, for example, Tchaikovsky's Symphony No. 4? Is it just a temporal se-

Malyshev I. Chronotope of a Piece of Music. http://www.proza. ru/2010/03/09/1185 
quence of sound sensations, or is it an integral sound structure and conception of a worldview?!

If it is the latter, it exists in its entirety simultaneously. Thus, we seem to approach the conclusions about immateriality and the timeliness of the existence of a piece of music, i.e. ideas that are the direct opposite of the ones set out in M.S. Kagan's book, and that are more popular in aesthetics. In fact, we only noted the vulnerability of the concept under analysis, and can acknowledge our failure to solve the problem of music's «chronotope». However, for its positive resolution, it has to be treated in a more comprehensive manner.."

In this case, the presentations (notions) of a theme, intonation, content, form-composition, are the expressive means, and it is them that create a place and frame for the musical pitch matter. Well, and what constitutes the whole for the expressive means as such? Can it be a personality? When reading, for instance, the biography of Glenn Gould, you grow more convinced in the assumption. «Glenn Gould as a result of thorough self-cultivation developed many qualities he hadn't had during his first performances: the steadiness of tempo-rhythm, the single pulsation of sounds and phrases, the denial of traditional legato and pedal principles, having gained control over each sound and each phrase. He overcame his drawbacks, having turned them into merits. That was the school of his own organization and overcoming, an attempt to find the balance between the emotional and the rational. And he succeeded..$\nu^{2}$ In continuation of this discourse, one may ask about the whole in relation to a personality. The answer will be paradoxical: the whole for a personality is both the personality itself that independently organizes its life, and the culture that «organizes» a personality.

In summary, I can say that we hear not isolated sounds, but musical events within the scope of the musical artistic reality, where the centrepiece is not the sound flow, but our own structures and attitudes. Let's say, when listening to a melody, we live through or imagine sadness, or the tranquil flow of clear water, or the slow falling of leaves. One should not think that the structure of sound flow is similar to the structure of the above events. In fact, what is there in common between these events, including the sounding flow? Nothing eventfully. However, in our experience we had the feeling of sadness, when simultaneously we were looking at the slow flow of water and falling leaves. And we try to fit that complex event on the sound flow (compare to how a child fits a melody on the movements of a goat). If we manage it, we feel sadness (the flow of water or the fall of leaves) in the form of a relevant musical melody. A lot

\footnotetext{
Ibidem.

Tina Gai The Doubles: Richter - Gould http://sotvori-sebia-sam. ru/svyatoslav-rixter/
}

here depends on a human: on his imagination, hearing experience, work of consciousness. The sound flow itself expresses nothing eventful. How come,- our opponent may ask, - and what about major or minor sound complexes, aren't they actually expressive in eventful terms? And still, there also exist major-minor and minor-major complexes!

Nevertheless, I do not want to assert the complete independence of the events of the organized sound complexes. Such dependence exists, but not in terms of connection of separate sound complexes with separate types of events. Systems and oppositions correlate, and that within the scope of a particular artistic culture. Thus, major and minor events, particularly in their opposition, are supported by corresponding sound complexes: the major key first has the major third, and then the minor third. And it is the opposite in minor key: first comes the minor third, then the major third. In both modes, the outermost sounds are located at the distance of the perfect fifth from each other. ${ }^{3}$ It is clear that those are just two different sound-complex structures, but such structures allow the implementationof two different music modes - major and minor ones, and, what is essential, in their opposition. In other words, when we hear a cheerful melody, we recognize that «cheerfulness» only in comparison with «sadness». Meanwhile, according to cross-cultural studies, cheerfulness and sadness are understood by different nations differently.

There is another aspect to be taken into account. One thing is the establishment of music, and another thing is its functioning. In the period of establishment, there is a certain competition between different sound complexes regarding their use in different types of events, and vice versa. Besides, sound complexes and events somewhat get «adjusted» to each other (musicians complete and reconstruct sound complexes until they find optimal variants). For instance, in the formation of classical music, as V. Konen shows, for the expression of grief and sorrow one should form special melodic turns (descending melodic motion, as a rule), chords corresponding to the minor mode, the rhythmic support of melodic turns (the dilation and special accentuation of the rhythm) and, finally, the ostinato approach (returning to one and the same motif). The entire musical complex in the context of empathy for opera characters (when, for instance, one listens to an aria) constitutes a complex sign, a musical expression of grief or sorrow. However, in the context of self-compassion, such a musical complex starts from

\footnotetext{
The minor mode consists of seven degrees (similar to the major mode). And further, everything is by analogy with the major mode: tonic, subdominant and dominant are called the main degrees. Other degrees are the secondary ones. Leading sounds gravitate towards the tonic (tend to resolution).
} 
a certain point evoking the listener's feeling of his own grief or sorrow. As a result, there form, on the one hand, special psychic phenomena - grief and sorrow lived through within music, and, on the other hand, - fragments (monads) of «pure music», i.e. a certain musical complex that already expresses nothing beyond its boundaries. Unlike regular grief and sorrow, musical grief and sorrow live in artistic reality (which is formed by sounding music and aesthetic events subordinated to the conditionality of art); however, the strength of feeling and suffering in this case falls not a bit, and often becomes even more intense. At the same time, comparable fragments of «pure music» have no meanings, but have their own energy charge, self-motion, own life (mental), i.e. form an independent reality.

And still, one should take into account the features of musical matter. First of all, it is known that sounds do not just follow each other, but sort of superimpose on one another: in a certain performance, we hear a new sound against the background of the previous one, which can still be heard in our consciousness. Here, music rests are also of great importance. It is such quality, which forms the material foundation for music timing.

Second of all, when compared to other art forms, music matter has a series of peculiarities.

- A sound, as such, carries no excessive or interfering associations, like, for instance, a word or human body that have different meanings. Therefore, one may assume that artistic events can be easier fitted on sounds.

- Sound matter is open to good organization (pitch organization, rhythmic, instrumental, etc.), which a human has been engaged in from ancient times. And together with the formation of music theory, such organization is being made based on complex sign systems and musical thinking (the science).

- Music expands the possibilities and abilities of a human tremendously, as a technique. With the help of musical instruments, a human grows himself a new "ear for music», and can listen to events that are impossible without such a technique.

Music intonations by B. Asafyev constitute a special case. A special part is played here by social factors. The fashion for various pieces of music, multiple performance of them (waltzes - in a city garden, marches - at a station, popular music by Tchaikovsky or Chopin), leads to the fact that not only certain sound complexes firmly stick to one's memory, but also the events and feelings connected with them. Having taken the notion of intonation as a basis, B. Asafyev

A new year for music is raised on the basis of music knowledge as well, for instance, the outstanding music experts (one of whom was, for example, Boris Asafyev) can hear tonic, dominant and subdominant in music. explains the change of musical events and sound complexes promoting them. ${ }^{2}$

In this case, there naturally appears a question, What does the phrase - «the expressive means» really mean? M. Beniumov makes the following definition: «Artistic means are the objectively fixed forms of the comprehension and organization of the musical activity. Or, these are the fragments of activity that were «stopped», and that «froze» within a semiotic space of musical language. An artistic medium, similarly to a sign, constitutes a semiotic object. But when a sign denotes its meaning, a medium denotes its purpose (function in the system) as well as its application method. When studying the means, we thereby study the activity, and get deeper into its very essence ${ }^{3}$.

I should explain the above definition. Expressive (artistic) means represent the figures, with the help of which an art theorist describes for other participants of artistic communication (for instance, for a composer, performer, critic, listener, - differently for each of them ${ }^{4}$ ) the means developing in their experience helping them to understand and create the artistic reality. It is in such figures, where such means are finally constituted and comprehended as expressive (artistic). As they are addressed to others and interpreted as standards of artistic activity, expressive means can be referred to as a technological scheme. It should be noted that various parts and aspects of artistic activity in the sphere of comprehension and studying "rest», and I would say «are constituted» in expressive means. In other words, expressive means are created within the applied science (art studies and theories of art).

M. Beniumov underlines another important feature of expressive means, and namely their historic nature. "The spheres of composers' and performers' creative work», he writes, "continuously change in historical terms. Correspondingly, the «lists» of performers' means used in different epochs, in different styles and genres, never fully coincide. Let us give only one example. In the age of the figured bass, the main features of the method of performance were the ornamentation and texture. However, later, such means lost

\footnotetext{
'New people, new ideological ambition, differently «tuned emotions»', writes Asafyev, 'evoke other intonations, or redefine the usual ones... the phenomenon of intonations explains the reasons of viability and non-viability of a piece of music. It also explains the meaning that was always inherent in music performance as the intoning, and revelation of the music before the public consciousness.' (Asafyev. Musical Form as a Process. L., 1971. P. 262, 357).

Beniumov M.I. Artistic means of a performing musician: paradox of the notion, historical genesis, structure, functions. Krasnoyarsk, 2012. P. 5.

For instance, M. Beniumov separates the composer's and performer's musical means, while analyzing their interrelations (ibidem, p. 10-11).
} 
their improvisatory nature and became predominantly characteristic of the composer's writing ${ }^{11}$

If from expressive means we proceed to music in general, we should speak not only about the historical change of expressive means, but primarily about the development of music itself that has to be understood in culturological terms. Within the scope of such an approach, we should say that music is formed as «new music» in every new culture (ancient, middle age, modern age). It goes through stages of its development within such cultures and undergoes a metamorphosis in later cultures. Meanwhile, new music assimilates all those elements and structures of the "old music» (truly speaking, having been subjected to essential reconsideration), but retains their relevance, and they keep on operating. Now, what is «the artistic form» as compared to the «expressive means»?

If expressive means, as technological «tools», allow the creation of the so- called «standard», characteristic of the epoch and of certain aspects of artistic practice and structures of artistic reality, then in the artistic form its unique, individual peculiarities are seized and constituted ${ }^{2}$. In order to better understand our assertion, let us consider the two cases - the expressive means that can be detected in one of A.S. Pushkin's poems, and the approach to building an artistic form in the play called Play... Schiller produced by R. Tuminas. Here is the poem by Pushkin.

\section{On the quiet banks of Moscow, The timeworn domes of churches Crowned with crosses glow Above the monastery walls. The never-cut groves have stretched Along the hilltops all around. The holy relics of a saint Have rested there since the olden times.}

The text structure of this marvellous poem reveals the following features (in Russian version): a neven, smooth rhythm; rhymes according to $\mathrm{aCaC}$ scheme; diverse semantic links (holy, relics, church, monastery, saint, cross, bank, hilltops, groves, etc.); the consecutive change of three themes (the view of Moscow, churches, monastery, the contemplation of nature, the presence therein of holy relics). Such and similar characteristics are obvious, and can be easily noticed by practically any reader. If it doesn't go beyond that (and such cases are quite frequent), a reader develops a reality similar to the one we described, that sets out the sequence of three themes, but is structured by the even and

Ibidem. P. 13. It is also worth noting that expressive means also became different - changed essentially.

Other definitions of artistic form exist as well, but for our subject of discussing the essence of music, it is this version, which is important. smooth rhythm and assonant-rhymed line endings (domes of churches, show in Moscow, monastery walls are outlined by crosses, holy relics rest among the hills and groves).

However, another perception and feeling is also possible. Let us look closely at it.

\section{On the quiet banks of Moscow}

Already the first line opens the whole world to us. We are standing on a bank, opposite Moscow. The word «quiet» refers this moment either to early morning or evening, or to the old, patriarchal Moscow, which is known to us only from pictures and novels of painters and writers of the XIXth century.

\section{The timeworn domes of churches \\ Crowned with crosses glow \\ Above the monastery walls.}

The world that opened before us gets a more specific description (confirmation) and unfolds further. Indeed, the perception of Moscow, especially in the XVIIIth, early XIXth century, is inseparable from the sight of churches, their domes (Gold-Domed Moscow), and the author is actually referring to old Moscow. (Nowadays, the picture of Moscow is different). It turns out likely that we see Moscow early in the morning or in the evening (the setting sun makes crosses glow). But there is also another theme - domes of churches crowned with crosses (as observations show, many people disregard it), which brings us into the other «overworld», the heavenly world. We acquire the feeling that Moscow is «the Spouse of Christ» crowned with churches, crosses and monasteries - that it is «a holy place», where the Grace of God rests and glows; this moment is also partially underlined by the word «timeworn». Thus, one starts feeling the contraposition and fusion of the two worlds - «the heavenly» and «the worldly», «under the sky» and «above the sky». Moscow is perceived slightly differently now: as a golden bridge connecting the two worlds, as a path from earth to heaven, and from heaven to earth.

Interestingly, the second theme not merely opens a new world, but also confirms it (a crown is put on the head - hence we have the «domes» of churches that represent their heads; an exceptionally strong visual image is the cross, which represents the crossing of the horizontal and the vertical, and both directions are confirmed: church domes are directed upwards, and monastery walls represent the horizontal; the cross is a symbol of divine energy, so it glows, etc.). The first four lines make us literally see; we get into the world that is maximally visualized and, therefore, emphatically sensual and real. (Here, probably, Pushkin draws on the rich visual experience of a Russian man, the 
practice of going to temples and observing all their interior decorations, examining numerous images of churches in paintings and engravings).

\section{The never-cut groves have stretched Along the hilltops all around.}

This theme makes us look around, step into a wider world, see hills and groves, feel the space spread over hills. At the same time, we start feeling the contraposition of the city to nature, of the closed city space, tightly filled with buildings, churches and monasteries to the open natural space of the retreating fields and hills, with their uncut groves. They are uncut probably also because they are holy.

The holy relics of a saint

Have rested there since the olden times.

The last theme sounds like the end and resolution; it supports and confirms the heavenly and the worldly life and simultaneously parallels the world of nature with the world of Moscow - both of them connect the heavenly with the worldly. Thus, Nature around Moscow turns out to be a holy place, where the holy relics have rested since the olden times. Moscow is not only the holy, God-blessed city by itself, but is also located in a holy place. The hypothesis that the groves are uncut, because they are holy, is also confirmed (never, since the olden times - they are «holy relics»). The assonance "rest - glow», the semantic connections (churches, monasteries, crowning God's saint, holy relics) and partially the rhythm, help bring the first two themes in contact with the next two, the world of Moscow with the world of Nature. Having connected the last theme with the first one (the holiness of Moscow with the holiness of Nature), Pushkin makes the reader's feelings "go round», i.e. he enhances and releases the initially-defined reality and tension many times.

Thus, at the end of the poem, all the themes gather together, and within the scope of artistic reality there occurs the release of all the feelings and tension (the holy city and Nature, the heavenly and the worldly).

Let us also make a point about the role of rhythm and time. The regular form and smooth rhythm maintains the reality of events: crosses glow, groves stretch, relics rest - all those events last in time, and the smoothness of their flow rests on the rhythm. The rhythm and time of the poem also create the harmony of sounding, proportionality and equilibrium that helps us realistically feel and live through the harmony of Divine holiness and Nature.

The analysis of this poem demonstrates that living through works of art involves the bringing to life, or «actualization» of a reader's or listener's experience (which in this case is represented by multiple associations, and images, and structures. As a result, there appears a series of events, a unique world, where a reader gets engaged. At the same time, events unfold in such a way that they make a reader acquire desires of an aesthetic nature, which can be immediately met, just like, for instance, in a series of pieces of music. However, the fulfilled desires get replaced by new ones. And still, sometimes the fulfilment of aesthetic desires is delayed, and the unification and resolution of all the themes takes place only at the end of a piece.

It is clear what is referred to "the expressive means» here (the poet's perception of rhythm, time, rhyme, themes, composition, etc.). It is more difficult to describe an artistic form. It is formed by: the artistic images and comparisons, the choice of words and themes, the logic of the organization of the total artistic reality.

The play Play Schiller...! has the following scene: Elizabeth, who is brilliantly played by Marina Neyolova, has to make a tough decision - to send her sister Maria Stuart to her doom. Elizabeth hesitates, but her counsellor, who is also present there, insists on the decision, appealing to the supreme necessity and her responsibility to the nation. In artistic terms, the scene is portrayed as follows: trying to make the tortuous decision, Neyolova walks about the stage in a stressedout manner, holding a tray in her hands with glasses brimful of water; whenever she doesn't manage not to spill the water, the counsellor immediately adds water, so that there constantly exists the need to hold the tray in a strictly horizontal position. One may ask, why not let Neyolova play this scene without any tricks, while demonstrating emotions alone? And that is because naked emotions don't touch us anymore: we have experienced them through thousands of paintings, theatre and cinema works, and often even in much more dramatic situations.

However, when we see Elizabeth, who alongside with making the existential and fatal decision carries a tray about the stage with water-filled glasses convulsively trying not to spill then, and her counsellor, who when adding water, all the time maintains that tension, we involuntarily start solving the puzzle proposed by Tuminas: what the tray and all of the rest actually means, etc. At the same time, we have to correlate the tray-balancing and the weird counsellor's actions with Elizabeth's feelings and, namely, with the clarification to her of the necessity to pursue her mission as a queen. That is, we start seeing the second with the help of the first, and namely due to their complete mismatch, the peripeteia with water become a new artistic form that allows a spectator to experience anew what is going on inside Elizabeth. One may notice that the new artistic reality also includes, as a necessary aspect, the purely artificial aspect as well. We go not only through 
the events Schiller writes about, but also through the way it is made by the stage director, and played by the actors. The necessary condition is also formed by our work on solving the puzzle set by the stage director, but not as the end goal in itself, not as a game for the game's sake alone, but in order to enter the artistic reality and fully live through its events.

Certainly, the new method of «mediation of one form by another» discussed here can be described exactly like a method and addressed to other stage directors; in this case, a new expressive medium would be created based on this reasoning. However, until it exists as a unique invention of Tuminas, inherent in the artistic text of the piece, it constitutes no expressive medium, but a new artistic form.

Let us dwell on the topic of expressive means in art a little more. If the latter constitute technological formations, then the interpretation of art as a technique should be discussed. Here, as I mentioned above, there are two artefacts: musical instruments and «the technique of creation» (composition, performance, understanding and feeling). As a rule, both the musical instruments and the technique are understood only as the means helping to create, perform and understand the music, but not as the ones that define its nature. In contrast to such an opinion, the following statement can be formulated: musical instruments and the technique of the creation of the artistic reality constitute the «social and musical body» of an artist (composer, performer, listener). «The Social body» - (the term is in general use in philosophy) should be understood as human possibilities and abilities constituted within and by the technique. (For instance, we move in a city with the speed of the transport vehicles, communicate with the help of mobile communications and the Internet, play and listen to music, use musical instruments, etc.). An ear for music and musical skills develop as a result of man's specialization and physical involvement in music: he hears with the help of musical instruments that enhance the sound, allow articulating and distinguish different timbres forming the sounding space, organize the sound in the most different terms'. But

'The music that is yours,' writes I. Vershinina, 'also lives in the voice of every musical instrument. In the early ballets of the composer (speaking of Igor Stravinsky - V.R.) I was amused by the chance of instrumental timbre staging. The score of Petrushka, for instance, was literally overflown with the voices of timbre-personages, timbrecharacters, expressing feelings, gestures and even speech of the live characters of the play. Those were the clarinet'laments of Petrushka in the 2nd scene', or the playful 'squabble of trombones and tuba with oboes (the witty talk of a goat with a pig) in the scene of mummers from the ballet finale.' At the time, when The Chronicle was planned, the composer was already interested not in the 'imitative' abilities of instruments, but in their own 'inimitable' voice. For instance, the clarinet in the Three Pieces for Clarinet Solo is not a timbre-character, as the clarinet in Petrushka was, but a'speaker' of a kind, who turns to a listener in his own'language.'The clarinet as such, just like any musical the words fail us. It is better to say not «with the help of technique», but «technique is something which transforms our «corporality» or sense of our physical existence, and way of life». Here, of course, we should explain the difference between the «body» and notions of «corporality».

It is common knowledge that all the body-oriented practices set and solve the task of the formation of the right techniques: techniques of movement, hearing, performance, energy distribution and so on and so forth. However, it is worth noticing, that the intent here is of no technical (creation of a living mechanism or a machine), but of quite a human nature. It is necessary to create a unique reality, where one could reach the states inaccessible out of such body practices. For instance, techniques used in karate allow a specialist to beat barehanded a physically stronger, or even an armed enemy. The "free dance» (a tradition coming from Isadora Duncan) technique plunges a spectator and participant in a dancing event into the reality of music and mythological time, where beautiful characters appear before him, and symbolic events are being lived through ${ }^{2}$. Classical ballet, rhythmic gymnastics and free dance have special technical methods that help achieve an amazing sensation of a human flying: he is not a bird, but flies up in the air, freezes above the ground as if floating above it. Analysis of body practices demonstrates that in order to turn oneself into a perfect technique, one should rediscover one's body: learn to move, hear, breathe, use one's energy anew; grasp (catch) new bodily sensations, remember them, find words for their denotation.

Speaking about «the body», we mean either the natural-scientific idea ('body» as a biological and physiological organism), or the aesthetic, or, finally, the practical idea (common understanding of a «body'). Psychology deals not with the body itself, but with certain changes in the body-connected consciousness, for instance, the disturbance of the figure, boundaries or sensations of the body. The category of corporal-

\footnotetext{
instrument or group of instruments, 'carries - according to Stravinsky the charge of emotionality, which is objectively inherent in its expressive means: the sound palette of its timbre connected with the sounding of different registers, the types of musical movement that are also connected with the character of sound articulation. A musical idea can be prompted to an author by peculiarities of the fingering of such an instrument, the way it was, according to Stravinsky, with him when he was composing Piano Rag-Music.'I was especially inspired by the fact,' recalled the composer,' that different rhythmic episodes of the play were prompted to me by my fingers. One shouldn't despise fingers: they are the great inspirers that often evoke our subconscious thoughts, which otherwise could have probably remained undiscovered.' (http://lib.rus.ec/b/354987/read).

Free dance is another face of authentism // Moscow Event. Dedicated to the $100^{\text {th }}$ anniversary of the first performance of Isadora Duncan in Moscow. 29 June - 14 July 2005. M., 2005.
} 
ity was initially introduced, on the one hand, under the influence of culturology and semiotics, where it was discovered that the body in different cultures is understood and perceived differently, and, on the other hand, as a result of the new understanding of such notions as disease, pain, organism, etc. (It turned out that they are not so much natural body states as cultural and mental concepts assignable (formed) and experienced by a human).

All these studies make us distinguish the notions of «body» and «corporality» by connecting the latter with the processes understandable within the culturalsemiotic and psychotechnical terms. Corporality is an innovation constituted by behaviour; it is something what the behaviour could not be formed without; it is the implementation of a certain cultural and semiotic figure (concept); and, finally, it is the corporality itself, i.e. the body's mode and organization. Corporality organs may appear and die during the life (according to the change and life of psychic structures and functions); spatially they may superimpose on one another and penetrate into each other (for instance, mouth as a body basis for a kiss, speech, eating and as an element of face's aesthetic image).

Larger units of corporality - body can also develop in a human (appear, live and die), for instance, «the body of love», "the body of thinking», «the body of communication», «the body of a pilot», "the body of a pianist», "the body of a karateka - or expert in karate», "the body of a dancer», etc.

Thus, we can assume that artistic reality is formed on the basis of two types of technique: the so-called «semiotic» technique (which is represented by rules of art and expressive means) and the «instrumental» one (instruments as such). Their impact promotes the formation of social bodies and multiply aggravate art effects.

\section{THE SPECIAL FEATURES AND CONSTITUTION OF MUSICAL REALITY}

Let us come back to the topic of music timing. Indeed, Malyshev was right when speaking about the non-temporary nature of expressive means: as the structures of musical language and activity, they really don't unfold in time. Nevertheless, the timing (procedure') of music cannot be ignored. "According to Stravinsky," writes I. Vershinina, «music more than any other art is capable of providing a listener with a possibility of direct contact with the substance of time. Perception of a piece of music by a listener is always a plunge and presence in the objective ontological time, even if a listener is

Let us recall the name of the classical work by B. Asafyev Musical Form as a Process. We should pay attention to the dialectics: a form as a category - not a process, and still, according to Asafyev, it is a process. possessed by a subjective impression from the timeprocess depicted by a composer. The time-presence, unlike the time-process, can be perceived and comprehended by a listener only within the boundaries of a clearly organized sound space or, in other words, «the particular arrangement» mentioned by Stravinsky. «lt is such an arrangement,»he asserts, «such an achieved order, that evokes an emotion of an absolutely unique nature, which has nothing in common with our usual feelings and responses to everyday-life experience.» In this case, it concerns the emotions of aesthetic pleasure, which is certainly characteristic of art in general. But nowhere else, except in music (except, perhaps, in architecture), such aesthetic pleasure can be so closely and directly connected with the construction of the artistic form. $»^{2}$

That «something», which is called a «time-presence» by Stravinsky, from the viewpoint of the theory of "psychic realities» as well as the notion of «timing», can practically without changes be understood as the life of the personality in two of its fore-mentioned dimensions (in the sense of the development of a human, and the transition from his one reality to another, including, naturally, living through the events of such realities). Then, there naturally arises the following question: «What problems, including existential ones (for serious music), does a human go through when listening to music, as there is that something that guides life?»

But, first of all, let me give you one illustration, paving the way for further thought. Olga Kondratyeva Popova, one of the leaders and initiators of «free dance» (which is more often called «the musical movement'), recalled the following in an interview:

"I was a child of awful psychic sympathy... It was very easy to come to everything, because my psyche was very sensitive, vulnerable, and life was... I was thinking for a long time, all these years and the previous ones (the girls - trainees - know), I often asked myself: what did «the musical movement» give me - support? Or vice versa? And only now I can say with absolute confidence: if there had been no musical movement, I could have come to any degree of mental disease. I am absolutely sure. And what is this? Well, this is the chance to pour out any or all of your unfulfilled feelings, and maybe even your entire life... I was given the real chance to express myself. To pour it all out, not to keep it to myself, not to push and go through it silently; as I was given the motor pathway to live through it in this activity... After all, I will repeat myself: we don't profess to dance authentic Bach — that can never happen! Do I dance the idea in Bach? I do. That is my feeling. And in that moment, perhaps, such states and such moods are actualized, which otherwise

http://lib.rus.ec/b/354987/read 
would be locked in my heart forever. And they would be gradually killing me. In other words, this activity is, obviously, some kind of a powerful breakthrough and a stream, which I let out of myself. Now, I am strongly convinced of that. This is the chance to live. And a chance to control your states of mind?»'

At first sight, it may seem, that Popova is guided by already established desires and problems ('unfulfilled feelings», as she said). But what do the expressions «pour out life, «chance to live» mean, provided that in the beginning of her creative career Olga Kondratyeva was only feeling the way of musical move, had to travel it all the way? Could she, having entered upon that path, realize what desires and feelings drove her? That is unlikely, because, on the one hand, the desires and feelings that drove her were changing, and, on the other hand, such problems and desires were acquiring their form and existence right in the logic of musical move. Shouldn't we make a different assumption? There are two categories of problems and desires. Some are the already established ones that can be blocked in certain situations: therefore psychologists call such structures «unfulfilled», and say that they require fulfilment. Others (for instance, like Jung's unrealized desire to break with his father and the church), though already crystallized as strained field, are still unrealized, because no way of solving them has been found yet, and no work on realization and understanding of such way has been performed. Only after the solution of such problems and desires (let us call them «the developing» ones) is found, and the work on their understanding is performed, one can realize and formulate what drove the human. The same was with Jung: only after he understood his fantasy, by the way within the scope of thinking and artistic discourse, he realized, what drove his desire to break with the church and his father.

I suppose, Popova, while speaking about herself, actually meant both categories of problems and desires - the unfulfilled and the developing ones. However, the second one predominated. She solved the developing problems on the path of musical movement. We should also pay attention here to another aspect - the aesthetic one. Timing of musical move (like of art, in general) is unique: it discovers the world — reality — for a human, where his dreams and desires come true, where he feels excited and wants to be. When we admire and say «What wonderful music!» or «What a beautiful dance!», it is that world we speak about.

And my daughter Vera solved her developing problem - to hear what the teacher and I could hear, on the way of getting to know music. Further on, I

Ailamazyan A.M., Tashkeyeva Ye.l. Musical Movement: Pedagogy, Psychology, Artistic Practice // Culture and Art. 2014. N 2. hope, the world of music became wonderful for her as well. If we speak in great historic terms, the developing problems of the modern European personality, starting from the Renaissance, were solved by a human in response to the development of classical music.

The special features of such music in a professional sense are quite well described by the «functional theory». The theory has two basic ideas: the first one lies in the availability in classical music of the "tonicdominant-subdominant» structure, which explains the origin of tension and release. The second one is as follows: the impact of the above structure and pattern extending to all chords and levels of music.

The functional theory in music, as I show in my research, in fact, plays the same part as the concept of central perspective in painting. Thus, the theory can be interpreted, firstly, as the construction of figures that contain in their structure the musical feelings of the modern European personality; secondly, as the task of a new musical reality, where the mentioned tensions and releases exist, and, thirdly, as a condition for its study and construction of a musical form, which is something L. Mazel writes about ${ }^{2}$. In its turn, musical feelings, and namely life in music, managed to resolve certain problems of the developing modern European personality.

What was the emotional world of the developing Modern-Age personality like? First of all, the «image of the self», of individual self as the source of life and decision-making, was in the process of formation: different realities as the conditions for independent behaviour were being established, attitudes to various life-forms were defined (some of them were considered as acceptable, and the others - as unacceptable and dangerous). Secondly, a human, after the Middle Ages, organizes his life in time anew, but this time not in the sense of salvation and transition to God, but in the sense of ordinary life ending with death. (This is what Heidegger meant speaking about the finiteness of Dasein time. Thirdly, he arranges his place in the outside world anew as well. And in all of the above three cases, the personality faces problems that can be interpreted as the developing ones. The latter appear because most of human actions are yet unrealized and, thus, the personality can hardly fulfil them, and also because often the exterior conditions or consciousness of the human being block such actions, though they were already actualized in consciousness and language.

Indeed, if, for instance, our realities are still unrealized, because they are only becoming established, we get confused in the transitions from one reality to another, or involuntarily block such transitions our-

Rozin V.M. Nature and Genesis of European Art (Philosophical and Cultural-Historical Analysis). M. 2011. P. 264-293. 
selves. If any events of the outer world are understood by us as threatening or indefinite (like, for instance, in our century), the tension and problems appear again. If we fail to recognize ourselves in different periods of our lives, because we changed essentially, problems with our identity appear.

Such problems used to be resolved in modern European art, in thinking (philosophy and science), and also in the process of the creation of classical music, where conditions were created for the specific gathering of all the three aspects of the developing modernEuropean personality, and namely the aspect of timing, the existence of its different realities, and the being in the world. The centre, as it was mentioned above, is occupied by the image of the individual self. The main problems are the ones connected with:

- the crystallization and fulfilment of desires of the individual self;

- the switch of realities (i.e. the transition from one reality to another);

- with experiencing (responses to the transitions and going through the events of reality);

- with personality confirmation or non-confirmation;

- with the acceptance or non-acceptance by a human of the individual-self events (on the basis of which emotions are crystallized with positive or negative signs).

Classical harmony, together with melodic and rhythmic beginnings was formed as the musical reality that allowed the solution the mentioned herein developing problems of the modern European personality we have already mentioned, while simultaneously constituting and structuring it anew. The roles were, obviously, distributed here as follows: harmony provided for mainly the general structure of personality confirmation, and partially for the fulfilment of aesthetic desires. (The constant returning to the leading note and tonic can be related to the individual self-confirmation, as well as the fulfilment of desires). A melody that included separate musical tempos, primarily, set an individual scenario of events and sufferings, which took place within the individual self, and connected previous events and sufferings with the following ones. Rhythm functioned as the power basis, as an eliminating engine, and supported events in the individual self, preparing them in the power sense.

One should have no illusions here: I do not postulate the establishment of unambiguous connections between certain personality structures and certain sound complexes. In this case, everyone would hear and understand music equally. The picture in life is different, however: everybody hears, understands and feels music differently, though there are common patterns of music perception and life characteristics of audiences at certain times and of certain types of music. In this respect, nothing can be said in principle (because all of that is individual and accidental) about the way problems of a separate person are resolved in music, what particular sound complexes his processes are based on, and what those processes are'. Besides - a point which I keep on underlining - all the formations (personality, its problems, ways of their resolution, sound complexes, etc.) taking part in such establishment are changing and adjusting to each other.

However, the space in which all such formations develop, is neither individual, nor accidental: it is formed by the time, in which a human lives, musical culture, and his personality. And namely, in the period when classical music was dominant, the musical culture was already quite complex, personality was developing along the mentioned three lines, and time, when compared with previous and subsequent epochs, was perceived in quite an optimistic manner.

A great part in the formation of common patterns of hearing, understanding and feeling music is played by forms of comprehending music, music grammars, music education and, finally, the very character of music life to a certain extent (concerts, music critic, copying and sales of pieces of music, etc.). The thing is that all such formations (for instance, music theories or techniques for composition or performance, critical reviews, comments for the public related to the performed pieces) are meant for others, for, so saying, average composers, performers and listeners, and for the mass music audience.

However, the music culture is composed of two spheres: the above mentioned sphere of mass music culture, where common patterns apply, and the true music life, where music geniuses (composers and performers) create masterpieces, and pieces of music are listened to and lived through by listeners in a unique manner (also like geniuses, one can say).

I think there is no need to prove the argument that music culture changes in the course of time, while it not only evolves within the scope of «great cultures» (the Ancient and Middle Ages, the Renaissance, the Modern

\footnotetext{
'We', writes Aida Ailamazyan, 'gave the simplest example, but even it shows how complex is the process of musical content formation and how unique is the musical language of every piece of music. The intonational, semantic content of separate means of musical expression (musical language) is generated only within a comprehensive piece of music, and the means of musical expression torn from the context and certain logic and the structure of a particular piece of music loses that semantic content. In order to discover those contents, it is necessary to do the work on the correlation of different musical fragments and episodes, separate elements of musical tissue and their aggregation. It does not always unfold linearly: contents can open slightly at first only in separate fragments of a piece of music; the process may unfold in time with multiple listening (and sometimes it may last for years).'(Ailamazyan A. On Mechanisms of Feeling Music: Experience of Musical Movement // Issues of Psychology No. 5, 2013. P. 35-43).
} 
Age), but also renovates (similarly to a «neoformation') in the transition from one culture to another, as well as within a separate culture, for instance, under the impact of intonation change or catastrophes (war, etc.). At the same time, the space, where common music patterns form, naturally changes as well: personality, artistic realities, temporality character and events experienced in the epoch.

I will describe in this respect one of the modern interpretations of culture and personality that dramatically differ from the ones the classical music grew on. «To be and to become one's own self - means to include one in the discussion nets... Multiculturalism,» writes S. Benkhabib, «too often sticks in the fruitful attempts to place the emphasis on one narrative as being the most essential one... A multiculturalist stands up against the perception of cultures as internally split and contestable. It is also carried over to his idea of personalities that are further viewed as equally consistent and harmonic beings with a special cultural centre. $\mathrm{I}$, on the contrary, consider individuality a unique and fragile achievement of personality, obtained as a result of the interweaving of the conflicting narratives and affections in a unique life history... Interpretation of cultures as air-tightly sealed subordinates of the own inner logic of the given things is untenable... Cultural assessments can pass over from one generation to another only as a result of creative and vivid participation and the meaningfulness obtained thereby anew.»"

Here, the culture and human have to be conceived within the notions of identity and reality that are established in the process of communication and dialogue, and that - every time anew ${ }^{2}$. And isn't it the personality meant by modern music, which develops a new organization of sound material, new expressive means and new aesthetics? «Culture of the 2 nd half of the XXth century,» writes Tamila Dzhani-Zade and Valida Kelli, «is marked by harsh rejection of the previous stylistic trends. The twelve-tone technique remained the most modern and basic one for most composersserialists of the 1940-1950s. Remarkable for the 1950s

Benkhabib S. Challenges of Culture. Equality and Diversity in the Global Epoch. M., 2003. P. 17, 19, 43, 122.

Compare. 'An awaking man, while speaking like Proust, asks himself: Why, when I wake up, me is me, and not somebody else? It is something,'says Mamardashvili,'one should think about.'And later:

We start understanding that the mystic feeling is, certainly, an attempt of a human to go back and resume a certain simple feeling of life as something, which, by definition, was not made and was not finished... Thus, we believe that Christ was crucified, and his agony took place. And the mystic feeling is the feeling of oneself present in the whole world, in all the events of the world: they happen when I am present. Therefore the Crucifixion belongs to human history to the extent, in which it is a lasting or an unfulfilled event, inside whereof we should not sleep. Such an event lasts forever.' (Mamardashvili M. Lectures on Proust. M., 1995. P. 302). was the response to the serial technique expressed in the article by French composer and conductor Pierre Boulez Schoenberg is dead! (1952). He, similarly to Italian composer L. Berio, criticizes creating music with the help of series, because such a method «has nothing to do with true music». The musical heritage of the XXthcentury composers contains numerous contradictory phenomena: neo-romanticism and sonorism, serialism and aleatory music, electronic constructionism and minimalism...

The new method of music composition had an experimental nature. The primary target of creative composing at that point was the search for new means of expression by means of «mastering» the source material, out of which the very ideas of «music» could be «taken»: the main focus of composers' attention turned out to be not the interval and rhythm, but the sound, its timbre, amplitude, frequency, length, as well as noise, rests, etc...

On the one hand, it was asserted that the basis of music was discursive-ordered thinking. Therefore, the priority was given to musical technologies and «formal order» that spread «to the depth of music at the level of microstructure». (Boulez). New rational methods of work with music attracted many of those, who had any relation to mathematical and physic-technical education (Boulez, Milton Babbitt, Pierre Schaeffer, and lannis Xenakis - the inventor of his own computer for the creation of electronic pieces with the help of programmes with compositions based on mathematical formulae and laws of physics). On the other hand, American composer John Cage involved with the Buddhism philosophy proposed the aesthetics of "silence in music» (see the book called Silence, 1969), while proving that music is not created on paper, but «is born from vacancy, from silence», that «even silence constitutes music». Such an idea was actualized by him in the famous soundless opus instructing a musician «to keep silence for 4 minutes and 33 seconds» before starting to play an instrument (4'33" tacet, 1952). The "Silent music» led to the creation of a new music genre - the instrumental theatre (in the work of German composer Mauricio Kagel (1931), Stockhausen, and the Italian composer Luciano Berio, 1925, etc.) ...

Many composers refer to the work of their classical predecessors not just for musical quotes, but also for musical reference to the compositions of Bach, Debussy, Berlioz, Beethoven, Mussorgsky, Stravinsky, using the "cutting» technique (as in Kagel's works) ...

Composers' interest in folklore takes new features. They don't just process their own musical folklore, but more and more often turn to the authentic musical documents of non-European cultures - ethnic and religious music of different nations, the wide access to which was promoted by the achievements of modern musical ethnography (and namely, of American ethno- 
musicology), as well as by composers' trips to the countries of Africa and Asia, with on the spot study thereby of traditional music practices (the Americans - Philip Glass, Stephen Reich, Terry Riley, Frenchman - Jean Claude Eloy, etc.). In the work of some musicians, modern writing techniques were successfully used for the expression of political ideas, or philosophical and cultural choices (oratorio Dies irae. In memory of the victims of Auschwitz, by Penderecki, and the vocal and electronic composition Non consumiano Marx, 1968, of the Italian composer Luigi Nono, 1924) ...

Demand for the visual appeal of musical concert performances, such as «show», grows: they start involving actors, mimes, costumes, light and sound effects. Concert conditions for music performance change, when musicians can be put into a cave for reaching the circular resonance, and listeners can be seated in suspended armchairs above the precipice. Special concert halls are being built (the Beethoven Hall in Bonn, 1970, Le Geod Hall - a construction in the Paris suburbs in the form of a sphere made of mirrorpolished steel, $36 \mathrm{~m}$ in diameter). Special electronic studios open, equipped with synthesizers, and they become the international centres for teaching new music (for example, the Georges Pompidou Centre in Paris) ... Creation of the music itself and texts about such music (e.g. the works of Messiaen, the manyvolumed publications of Stockhausen, and articles by Cage, etc.) are characteristic features of the composers' creative work in the XXth century...

By the end of the XXth century, avant-gardism exhausts itself, while exerting an impact on other types of music culture - on jazz, rock, cinema music. The outcome of this was the development in contemporaries of a new idea of music, and new attitude to the material it is made of, and that now music includes the widest range of all the known historical and geographical styles and sound-instrumental technologies. While being just like the high musical art in Europe an élite phenomenon - the avant-garde gets lost in everyday culture, which enjoys its triumph to this day. The characteristic new musical forms of avant-garde styles of creating music with the help of computer programmes and exclusive sound technologies give birth to a new type of non-academic music activity accessible to an amateur musician, who tries to learn the laws of building a piece of music beyond the walls of traditional professional music institutes' ${ }^{\prime}$.

Let us go back now to the beginning of this paper and briefly answer the questions put there, though, in fact, it is them we were trying to answer. Music has a powerful impact on us, because it gives an opportu-

Tamila Dzhani-Zade, Valida Kelle Western-European Music. (http:// school-collection.iv-edu.ru/dlrstore/5cd4876e-1c43-b264-df292281f8333f9c/1012101A.htm). nity for us to solve our own problems (the developing, existential and unfulfilled ones), and allows us by that means to renew and continue in our lives. Music is not just sounds, but also a musical reality, a complex music culture and, finally, it has quite a sophisticated technique. We feel the ecstatic influence of music when we manage to go through our existential problems in music. Though music is performed and sounds outside us (even when we croon something to ourselves), it is felt as something sounding inside our heart, which is quite clear, taking into account the work of our consciousness and psyche. It is we, who by such actions, while responding to our problems, arrange the events of musical reality and simultaneously live through them. Music is not a language, but a symbolic form of life fulfilled uniquely by each personality. As music culture, music possesses patterns, including the language ones.

The mystery of music can be demystified, if we look at it through the prism of «realias», or real life objects listed here. However, such mystery still exists, because the "realias» are actualized in the unique creative work of a composer, performer and listener ${ }^{2}$. And this is not all. The mystery of serious music lies in something else, perhaps, in the peculiar spirituality and transcendence that was pointed out to me by Aida Ailamazian, when I introduced her to the ideas set out here. And I had to agree with her, having recalled that many great artists and musicians underlined this spirituality of art, as well as their devotion to it. Our remarkable composers and performers speak about music not merely as of a profession or work of art, but as of a certain sublime life sphere that exists somewhere (both, in the transcendental space and right here) and requires devotion and adoration.

\footnotetext{
Compare with what Boris Asafyev wrote.'The most difficult thing, but at the same time the highest point to be achieved in this work on the composer's ear for music, is to learn to hear - or to perceive with the full awareness and breathless attention - music with the simultaneous embracement of all its 'components' that the ear reveals; but in such a manner, so that each second of sound motion is comprehended in its connection with the previous and the following one, and it is instantaneously defined whether such connection is logical or illogical - defined by the immediate intuition, without recourse to technical analysis. Musical content comprehension of the kind marks the highest level in the development of the inner ear for music, and has nothing in common with formal analysis. A good exercise when still on your way to it is to play to yourself the pieces of slightly unusual forms, demanding from your ear the up-to-thesecond awareness of the 'logic of the sounding flow unfolding', or rather of the intonational and meaningful opening of music similar to live speech. It is very difficult to pick words that can describe the auditory perception, the'narration'refers to here: only a musician risen above the purely handicraft or even focused-professional hearing on a string of theoretical conditionalism, can truly understand the above process of the deeply conscious perception of music as the sense, without resorting to its grammar and syntax.' (Asafyev B. Musical Form as a Process. Book One and Two. L., 1971. P. 234-235).
} 
What is more, Aida noted the «psychological logic» of my understanding of music. Indeed, it turns out that within my line of thought music, on the one hand, represents a condition for the resolution of various problems of an individual, and on the other hand, it forms that very personality in the sense of temporality, eventfulness, and the possibility of realization. At the same time, from Aida's viewpoint, the mystery of music cannot be explained in purely psychological pattern: it is required, but cannot be adequately given. The psychological context has to be amended by another, which I understood as the spiritual and phenomenological context. While thinking over Aida's remarks, I added a couple of other observations.

In the Symposium and a series of his other dialogues, Plato for the first time discusses what I would refer to as the spiritual and phenomenological and transcendental reality. One of the main characters of the Symposium, the priestess Diotima, says that love is the bearing of spiritual fruit, and the heart is meant for bearing the good, the beauty and the immortality. That, in my opinion, is one of the first conceptualizations of the spiritual and phenomenological world. If we consider some other of Plato's dialogues, this world can be described as follows: the spiritual and phenomenological world (reality) represents a «path» and «work» focused not only and not so much on the personality as such (which is certainly implied) as on the ideas and "schema'(or shape/plan) of the good, the the beautiful, the eternal life, the gods, heaven, salvation, etc.), as well as on the «social whole» (the same idea of the good; as Aristotle will later say, the good of a separate human is certainly wonderful, but the common good is of much greater importance.')

The spiritual and phenomenological reality cannot be understood as an object or device, or as a world that came into being, as it is the actual path and work - the lifestyle that leads to salvation (which later in culture correlates with the sense of life) and is in many aspects connected with restrictions, a personality develops towards, and tries to implement in life. When saying that the heart is meant to bear beauty, Plato points also to such an important condition of salvation as art in its broad sense. Later, in the Middle Ages and further, in the modern times, we observe various conceptualizations of such a condition, starting from the concept of music as «the imitation of the

'Apart from other things,' the Stagirite writes, it is hard to put into words the delight in the awareness that something belongs to your, for the feeling of love to one's own self inherent in everyone is no accident, but was injected by nature $<\ldots>$ The good of one man is obviously desired, but there is more beauty and divinity in the good of the nation and the state» (Aristotle. Politics // Composition in 4 volumes. V. 4. P. 410). sound of the heavenly spheres», and further towards Heidegger's ideas that art is the house of being. (Tthe truth of being» is revealed, discovered and maintained in art: «A work of art reveals, by its means, the being of things in existence. Creation fulfils such revelation or discovery, i.e. the truth of things in existence. $\left.\nu^{2}\right)$ Merab Mamardashvili writes about the same things, but in a slightly different manner, saying that a work of art gives birth to both an artist and a spectator).

However, if before ancient culture art fails to stand out from the common syncretic whole of spiritual life, as, for instance, spirits were raised by primitive people while creating rock engravings and primitive sculptures. (In this respect, a primitive man would probably understand Heidegger.) Then, starting from Aristotle's works art becomes differentiated into an independent reality and life sphere. By enduing art with the function of «imitation» or «mimesis»), and further of «expression», an art philosopher and art expert separate life from art, at first, by means of the loss of the latter's connection with the spiritual and phenomenological reality. And in the same breath he tries to recreate such a connection. Subtle artists feel it always. Here is what Marina Tsvetayeva in the remarkable article called Art in the Light of Conscience writes:

«The artist's timidity before an object: he forgets that it is not him who writes. If to put the words of Viacheslav Ivanov into my mouth, — «You only have to start! Already from the third page, you will find that there is no freedom,» - that is: I will find myself in the grip of objects, i.e. in the grip of a demon, i.e. just an obedient servant $\langle\ldots$.. $>$ And what is the part of will in all that? Oh, it is great. At least not to become desperate, when indulging in vain hopes $<\ldots>$ My will is hearing, not to get tired of listening, until you do hear, and to carry nothing you haven't heard. $\nu^{3}$

However, I think that it is both of them who write poems - the poet and the Poetry together. The poet expresses himself and makes poems, and does that not at random, but pursuing the logic of poetry, while cultivating the language of art. Poetry, itself, cannot write and make poems, and does it through a poet. In other words, it is symbiosis and synergy. But then, there is something that depends on the poet's personality as well. It is problems discussed by him, his attitude to the events he engineers, the very nature of feelings fulfilled in the events of artistic reality. But insofar as the poetry and its language are simultaneously deindividual, they don't depend on the poet's personality. It is interesting that relations of Art and the artist are not always serene - quite often they are tragic. Let us compare Tsvetayeva and Boris Pasternak.

\footnotetext{
M. Heidegger. Works and Reflections of Different Years. M., 1993. P. 72. http://www.pergam-club.ru/book/6492
} 
The life of Pasternak was practically perfect in moral terms, and the life of Tsvetayeva, on the contrary, was worth, even if not condemnation, then, in any case, pity. However, the poetry of both of them was wonderful and ingenious. So now we perceive the poetry of both of them through the prism of the life of such authors. Pasternak's poetry will, certainly, stand the trial, but there are certain doubts about that of Tsvetayeva. But, I think, she will stand it as well, because the restless, intelligent, dual personality, which is also selfish and immoral, unfortunately acquires in modern culture an increasingly mass character. One can regret it, one can ask a question, what is to be done about that, but one cannot deny the fact that such a state of affairs will for a rather long time remain our reality, which has to be taken by art out of the non-existence and comprehended.

It is interesting how Tsvetayeva discusses this topic herself. On the one hand, she seems to demand that an artist should be a moral personality that doesn't mindlessly obey the power of Art:

«Thus, a work of art is the same work of Nature, but the one that is obliged to be the enlightened radiation of mind and conscience. Then it serves the good, just like good is done by a stream spinning a mill wheel. But to say of a work of art that it is the good is the same as to say of every stream that it is useful. Sometimes it is useful, but sometimes it can be harmful as well, and it is harmful so much more often!» «We could have, perhaps, not got tempted by the second part of Dead Souls. But we would definitely rejoice at them. However, our rejoicing at it in that way would be nothing compared to our rejoicing at Gogol in this way. Gogol, out of love to our living souls burned his Dead Ones. In the fire of his own conscience.» «lf my things release, enlighten, purify - it is a "yes»; if they delude - it is a "no», and I would better have a millstone hung about my neck.»'

On the other hand, Tsvetayeva insists that an artist, especially a genius, is beyond morality, as he resignedly fulfils all the requirements of Art:

«Artistic work in some cases is a certain atrophy of conscience, and I will tell you more: it is the necessary atrophy of conscience, that moral defect, without which it, the art, cannot exist. In order to be good (not to drive the little ones into temptation), art would have to refuse from a good half of itself. The only way for art to be knowingly good is not to be. It will end with the life of the planet... «An exception in favour of a genius». Our entire attitude to art is the exception in favour of a genius. Art as such is actually the genius, in favour whereof we make exceptions (inclusions) from the moral law.» «The state of creativity is the state of a night dream, when you all of a sudden, while obeying a strange necessity, set a house on fire or push your friend off a mountain. Is it something that you did? It obviously is (you are asleep, but it is you who is asleep!). It is what you did, while being absolutely free, without conscience, like you were being the nature.» «A poet is often being compared to a child based on the feature of innocence alone. I would compare them basing on their irresponsibility. Irresponsibility in everything, except the playing..2²

And here is the conclusion proving that Poetry was the most important thing for Tsvetayeva, and she knew it perfectly well:

«Therefore, if you have any desire to serve God or people, or, generally, if you want to serve, to do the good, go to the Salvation Army or somewhere else and give up poems ... And while knowing that, having put my name to it in sound mind and memory, in the equally sound mind and memory I say that I would never change my passion to any other. While knowing the greater, I create the lesser. Therefore there is no mercy on me. It is only the ones as I am that will be held accountable at the Judgment Day of conscience. But if the Judgment Day is all words - I will be innocent then.» ${ }^{3}$

What can we understand from the above speculations of Tsvetayeva? Among other things, the fact that there are personalities that live in two worlds at once: the world of art and that of spiritual making. To be more accurate, the artistic work and creation is perceived and practised by them as a spiritual path, and, vice versa, salvation for them is to live in art. Music is not an exception, and is maybe the most adequate (essential) medium of the similar mental outlook and life. And here is why First of all, its material (sound complexes), as it was mentioned above, is free from the accompanying interfering associations and images: it is open to good organization (which is superior to the organization in other art forms), and is supported by powerful instrumental means. Secondly, music has been historically based on well-developed reflection and knowledge. This is why music naturally works for the spiritual and transcendental realities, and the latter ones, in their turn, work for music. What does it mean for music? It means that music exists and develops not only in relation to psychological problems of the artist's and listener's personality, but also in relation to the deindividual social whole and spiritual life at the same time. Music works for the personality (hence we have the psychologism) and for the social whole (musical language and grammars, music as a technique), as well as, which is of equal importance, for

\footnotetext{
Ibid.

3 Ibid.
} 
the spiritual path of a human, for the transcendental reality. Consequently, music develops as a form of the psychological life of a human, and as a form of his social and spiritual life, but it never strictly coincides with the three mentioned realities (psychological, social and spiritual-phenomenological ones). This is one of the reasons why composers, performers and listeners feel music as an independent reality, with its own developmental laws.

A true artist never confuses music with spiritual and phenomenological reality, but always feels their connection and interdependence. It is not that he merely composes, performs or listens to a piece of music, but he tries to join in the true spiritual lifestream showing in such pieces. «To join in» means at the same time to discover, and arrange such flow. But isn't it here, where the phenomenon of the amazing influence of music on a human lies? It is when an artist (a composer, performer, listener) follows two paths at once - that of art and of spiritual making - when he manages it, when he is able to, at least partially, pass his success over to the others; it is in such happy and so infrequent moments, when one can reach the "catharsis», Aristotle wrote about. So this is my understanding of the phenomenon of music, of its mystery and amazing impact on a man.

\section{REFERENCES (TRANSLITERATED)}

1. Tamila Dzhani-Zade, Valida Kelle Zapadnoevropeiskaya muzyka. (http://school-collection.iv-edu.ru/ dlrstore/5cd4876e-1c43-b264-df29-2281f8333f9c/1012101A.htm)

2. Stravinskii I. Khronika moei zhizni. M., 2005.

3. Svobodnyi tanets - drugoe litso autentizma // Moskovskoe deistvo. 100-letiyu pervogo vystupleniya Aisedory Dunkan v Moskve posvyashchaetsya. 29 iyunya - 14 iyulya 2005 goda. M., 2005.

4. Prokof'ev S.S.. Materialy. Dokumenty. Vospominaniya. M., 1961.

5. Rozin V.M. Fenomen mnozhestvennoi lichnosti. Po materialam knigi Daniela Kiza «Mnozhestvennye umy Billi Milligana». M., 2008, 2012.

6. Rozin V.M. Semioticheskie issledovaniya. M., 2001.

7. Rozin V.M. Psikhicheskaya real'nost», sposobnosti i zdorov'e cheloveka. M., 2000.

8. Rozin V.M. Psikhologiya: nauka i praktika. Uchebnoe posobie. OMEGA-L. M., 2005.

9. Rozin Vvedenie v skhemologiyu. Skhemy v filosofii, kul'ture, nauke, proektirovanii. M., 2011.

10. Rozin V. M. Vizual'naya kul'tura i vospriyatie. Kak chelovek vidit i ponimaet mir. Izd. 5. M,. 2012.

11. Rozin V.M Osobennosti diskursa i obraztsy issledovaniya v gumanitarnoi nauke. M., 2008

12. Rozin V.M.. Razmyshleniya ob arkhitekture (dialog, initsiirovannyi Aleksandrom Rappaportom) // Kul'tury i iskusstva. 2013. N 5.

13. Rozin V.M. Stanovlenie i teoreticheskoe osmyslenie v kul'ture Novogo vremeni klassicheskoi muzyki // Kul'tury i iskusstva. 2013. N 3.

14. Rozin V. M. Genezis evropeiskogo iskusstva (filosofskii i kul'turno-istoricheskii analiz). M., 2011.

15. Polyakov M. Ya. Voprosy poetiki i khudozhestvennoi semantiki. M., 1978.

16. Melodiya // Muzykal'naya entsiklopediya - Opera, 2008 (http://www.music-dic.ru/html-music-enc/g/1988. html)

17. Mamardashvili M. Literaturnaya kritika kak akt chteniya // Kak ya ponimayu filosofiyu. M., 1990.

18. Mazel» L. Problemy klassicheskoi garmonii. M., 1972.

19. Konen V. Teatr i simfoniya. M., 1968.

20. Malyshev I. Khronotop muzykal'nogo proizvedeniya. http://www.proza.ru/2010/03/09/1185

21. Vershinina I. Kommentarii k knige Igorya Stravinskogo Khronika moei zhizni. http://lib.rus.ec/b/354987/read

22. Vol'nov V. Fenomen muzyki. http://www.v-volnov.narod.ru/SmallWorks/PhenomenonOfMusic.htm

23. Bychkov Yu.N. Iz istorii uchenii o lade i garmonii. Lektsiya po kursu «Istoriya muzykal'no-teoreticheskikh sistem». M., 1993.

24. Benyumov M.I. Khudozhestvennye sredstva muzykanta-ispolnitelya: paradoks ponyatiya, istoricheskii genezis, struktura, funktsii. Krasnoyarsk, 2012.

25. Bakhtin M. Voprosy literatury i estetiki. M., 1975.

26. Benkhabib S. Prityazaniya kul'tury. Ravenstvo i raznoobrazie v global'nuyu epokhu. M., 2003.

27. Asaf'ev. Muzykal'naya forma kak protsess. L., 1971.

28. Bakhtin M. M. K metodologii literaturovedeniya // Kontekst. 1974. M., 1975.

29. Ailamaz'yan A.M., Tashkeeva E.I. Muzykal'noe dvizhenie: pedagogika, psikhologiya, khudozhestvennaya praktika // Kul'tura i iskusstvo. 2014. N 2.

30. Tina Gai Dvoiniki: Rikhter — Gul'd http://sotvori-sebia-sam.ru/svyatoslav-rixter

31. Todorov Ts. Poetika // Strukturalizm «za» i «protiv». M., 1975.

32. Khaidegger M. Vklady v delo filosofii. Ot sobytiya // N 1 (1) 2009. 
33. Khaidegger M. Raboty i razmyshleniya raznykh let. M., 1993.

34. Shestakov V. Esteticheskaya filosofiya S'yuzen Langer. http://philosophy.ru/library/langer/pril.html

35. Shnitke A. G. Slovo o Prokof'eve // Besedy s Al'fredom Shnitke. M., 1994. http://lib.rus.ec/b/354987/read

36. Yung K. Vospominaniya, snovideniya, razmyshleniya. Kiev, 1994.

37. D. A. Zhurkova Muzyka kak fon povsednevnosti: funktsii i osobennosti vospriyatiya // Kul'tura i iskusstvo.-2011.-4.-C. 66-73.

38. S.T. Gubina Tipologii muzykal'nykh predpochtenii: psikhologicheskie tipy bytiinogo i defitsitarnogo vospriyatiya muzyki // Psikhologiya i Psikhotekhnika._2013._-5. C. 433-439. DOI: 10.7256/20708955.2013.5.7304. 